\title{
Disciplina, conflicto, violencia y honor: la jurisdicción interna del cabildo catedralicio de Santiago de Compostela (1465-1602)
}

\author{
Arturo Iglesias Ortega ${ }^{1}$
}

Recibido: 4 de julio de 2021 / Aceptado: 13 de octubre de 2021

Resumen. El cabildo de la catedral de Santiago de Compostela gozaba de competencias jurisdiccionales que entraron en conflicto con las limitaciones que su arzobispo trató de imponer desde el fin de la Edad Media. Partiendo de las actas capitulares y los protocolos notariales, analizamos la evolución de los delitos de violencia e indisciplina cometidos por el personal catedralicio juzgados a través de la vía capitular de corrección y punición denominada Beate Jacobe para comprobar los efectos del Concilio de Trento.

Palabras clave: Conflictividad; disciplina; justicia capitular; Santiago de Compostela; siglo XVI; violencia.

[es] Discipline, conflict, violence and honor: the internal jurisdiction at the cathedral chapter in Santiago de Compostela (1465-1602)

\begin{abstract}
The Cathedral Chapter of Santiago de Compostela had got jurisdictional competencies that conflicted with the limitations that its archbishop tried to impose since the end of the Middle Ages. Starting from the Chapter acts and the notarial protocols, we analyze the evolution of violence and indiscipline crimes committed by the cathedral staff and judged through the Chapter way of correction and punishment called Beate Jacobe to verify the effects of the Council of Trent.
\end{abstract}

Keywords: Chapter justice; conflict; discipline; Santiago de Compostela; violence; 16th century.

Sumario: Potestad jurisdiccional del cabildo compostelano. Corrección y punición de delitos: $O$ beate jacobe. Conflictividad jurisdiccional arzobispo-cabildo. Análisis de los casos registrados. Fuentes, número y evolución. Tipos de delitos. Condenados y agredidos. Penas y castigos. La reincidencia. Solidaridad en la violencia. Conclusiones. Bibliografía.

Como citar: Iglesias Ortega, A. (2021). Disciplina, conflicto, violencia y honor: la jurisdicción interna del cabildo catedralicio de Santiago de Compostela (1465-1602), en Cuadernos de Historia Moderna, 635-666.

\footnotetext{
Archivo Catedralicio de Santiago de Compostela

ORCID: https://0000-0002-2501-9248

E-mail: moderna@catedraldesantiago.es
} 


\section{Potestad jurisdiccional del cabildo compostelano}

Desde el punto de vista jurisdiccional, el cabildo de la catedral compostelana, como el resto de los cabildos castellanos, fue consolidando sus privilegios, exenciones, atribuciones y prerrogativas a lo largo del período medieval a partir del derecho, la costumbre y las concesiones de sus prelados, siendo la más importante y duradera el gobierno ordinario de la archidiócesis en sede vacante, lo que implicaba asumir la mayor parte de los poderes y facultades que los arzobispos tenían en sede plena, entre ellas la de impartir justicia en lo espiritual en todo su territorio diocesano y en lo temporal en todos los territorios que conformaban su señorío jurisdiccional. En la práctica, son períodos de debilidad del señorío arzobispal que aprovechan la Corona y el concejo compostelano para tratar de limitarlo, del mismo modo que el cabildo para obtener una mayor autonomía frente al poder episcopal ${ }^{2}$. En cualquier caso, el cabildo no dejará por ello de ejercer interinamente las prerrogativas jurisdiccionales de su prelado, incluso en época moderna: por ejemplo, a lo largo del siglo XVI se ocupó de nombrar o confirmar inmediatamente a los vicarios, jueces y principales oficiales de la diócesis y del señorío ${ }^{3}$ o incluso de establecer en 1550 unas ordenanzas para la administración de justicia ${ }^{4}$. Hubo también ocasiones extraordinarias en sede plena, en las que el cabildo asumió algunas de esas prerrogativas: por ejemplo, en 1468, durante el destierro del prelado y la ausencia del provisor y otros jueces arzobispales, ordenó al obrero de la fábrica que "touese huna cadea con seu candado ena torre que esta çerca da torre dos synos e touese cargo dela para en ela prender, pugnir e castigar qualquer clérigo que feser algún delito ou mal quando mandase o dito vicario ou o cabildo" para atajar el intervencionismo de los jueces seglares 5 .

El cabildo, además, disfrutaba de una cotitularidad simbólica del señorío de la Tierra de Santiago, subsidiaria del poder episcopal, desde el nacimiento de dicho señorío en 1120. De esa cotitularidad en sede plena tan solo aflora testimonialmente la presencia capitular en el gobierno del señorío de la ciudad compostelana en dos aspectos: la elección de las dos justicias clérigas o alcaldes del cabildo que participaban en las reuniones concejiles, y la recepción del juramento de los alcaldes compostelanos ${ }^{6}$.

Sobre el papel del cabildo en sede vacante durante el Medievo, véanse Pérez Rodríguez, F. J.: La Iglesia de Santiago de Compostela en la Edad Media: el Cabildo Catedralicio (1100-1400), Santiago de Compostela, Xunta de Galicia, 1996, pp. 179-183; Vázquez Bertomeu, M.: La institución notarial y el cabildo compostelano (1460-1481), Santiago de Compostela, Universidade de Santiago de Compostela, 1996, vol. 1, pp. 52-54 y $57-$ 58.

3 Véase López Ferreiro, A.: Historia de la S. A. M. I. Catedral de Santiago de Compostela, Santiago de Compostela, Imp. y Enc. del Seminario Conciliar Central, t. VIII, 1905, pp. 83-84, 98-99, 115, 119, 132, 237, 245, 282 , 288,300 y 364 .

$4 \quad$ Ibidem, Apéndices, pp. 135-136.

5 Auto sobre juzgar y castigar a los clérigos de la diócesis que delinquen, Santiago, 3 de octubre de 1468, Archivo Catedralicio de Santiago (ACS), IG 475, Actas, Libro nº 1, fol. 66; cit. en López Ferreiro, op. cit. (nota 3), 1904, t. VII, pp. 255-256.

6 Véanse Pérez Rodríguez, F. J.: El Dominio del Cabildo Catedral de Santiago de Compostela en la Edad Media (Siglos XII-XIV), Santiago de Compostela, Tórculo Edicións, 1994, pp. 87-88 y 143-145; idem, op. cit. (nota 2), pp. 164-166; Vázquez Bertomeu, op. cit. (nota 2), pp. 59-62; Iglesias Ortega, A.: La catedral de Santiago de Compostela y sus capitulares: funcionamiento y sociología de un cabildo en el siglo XVI, A Coruña, Diputación Provincial de A Coruña, 2012, pp. 219-220. 
Por otra parte, como senado y cuerpo auxiliar del arzobispo, muchos de sus miembros participaban en su administración judicial, ocupando sus más altos cargos (provisores y jueces de la audiencia arzobispal) ${ }^{7}$, y algunas dignidades que formaban parte de la corporación capitular ejercieron la potestad jurisdiccional en nombre de los prelados (el deán y los arcedianos de Cornado, Nendos, Salnés y Trastámara, actuando como sus vicarios y ejerciendo como jueces eclesiásticos en sus respectivos arcedianatos, al menos hasta el Concilio de Trento; y los jueces de Luou y Villestro, actuando como jueces civiles en todo el arzobispado hasta que perdieron sus atribuciones jurisdiccionales probablemente en la segunda mitad del siglo XV en favor de los jueces ordinarios de la audiencia arzobispal) ${ }^{8}$.

Paralelamente, el cabildo fue adquiriendo a lo largo de los siglos distintos cotos ubicados en lugares y feligresías, integrados en los prestimonios o préstamos medievales que formaban parte de las prebendas canonicales o en las tenencias administradas por sus miembros, de tal manera que sus titulares - prestameros y tenencierosejercían como señores en dichas jurisdicciones en nombre del colegio capitular' ${ }^{9}$. De igual modo, determinadas dignidades del cabildo compostelano gozaban de señorío jurisdiccional sobre diversas parroquias y territorios anexos a ellas, en las que nombraban jueces pedáneos ${ }^{10}$.

Por último, por un privilegio real de 1615, el cabildo y el arzobispo de Santiago de Compostela gozaron del derecho a nombrar alternativamente jueces protectores que entendiesen en primera instancia en las causas relativas al Voto de Santiago de su tribunal correspondiente (Real Audiencia de Galicia, Real Chancillería de Valladolid y Real Chancillería de Granada) ${ }^{11}$.

He hablado hasta ahora de las principales competencias del cabildo y sus capitulares en lo que a la administración de justicia se refiere, pero he dejado para el final la que afectaba directamente al ámbito catedralicio y a su clero ${ }^{12}$. En virtud de su pertenencia al estamento eclesiástico, toda la clerecía catedralicia estaba exenta inicialmente de la justicia civil, pero es que, además, los miembros del cabildo gozaban de una situación singular de privilegio social a la hora de entrar en litigios ante la ley gracias al estatuto Cum sanctorum patrum redactado en 1306 para defenderse de los ciudadanos de Santiago ${ }^{13}$-basado en otro de 1271 y ambos acordados precisamente

Véanse Pérez Rodríguez, op. cit. (nota 2), pp. 184-189; Iglesias Ortega, A.: "El curriculum vitae de los capitulares en el siglo XVI: el ejemplo del cabildo catedral de Santiago", Historia y Genealogía, 2 (2012), pp. 148-152, 162,165 y 167.

8 Véanse Pérez Rodríguez, op. cit. (nota 2), pp. 58-59, 62 y 71-75; Vázquez Bertomeu, op. cit. (nota 2), pp. 83, 87 y 386; Iglesias Ortega, op. cit. (nota 6), pp. 65-66 y 72-74.

9 Véanse Pérez Rodríguez, op. cit. (nota 6), pp. 88-121; Vázquez Bertomeu, op. cit. (nota 2), pp. 62-64 y 186-187.

10 El deán era señor de la villa de A Pobra do Deán y, desde fines del siglo XVII, del coto de Sigüeiro y Trasmonte; el arcediano de Reina, de Santa María de Lampai; el arcediano de Santiago, de Santo Ourente de Entíns y Santa Baia de Chacín; y el arcediano de Trastámara, de la villa de Cee (Iglesias Ortega, op. cit. (nota 6), pp. 55, 58, 60, 62,67 y 69-70).

11 En Granada, el cabildo ya nombraba protectores desde 1566 (Rey Castelao, O.: El Voto de Santiago. Claves de un conflicto, Santiago de Compostela, Xunta de Galicia, 1993, pp. 28-32).

12 Recordemos, además, la especial inmunidad de que gozaban las personas recogidas en las catedrales por derecho de asilo (véase Sánchez Aguirreolea, D.: "El derecho de asilo en España durante la Edad Moderna", Hispania Sacra, 55 (2003), pp. 571-598) y la de los peregrinos a Compostela (López Ferreiro, op. cit. (nota 3), pp. 38-39). En el archivo catedralicio puede consultarse el legajo ACS, IG 420, Inmunidad eclesiástica. Refugiados en la S.I. (1724-1813).

13 Sobre la defensa que los cabildos articularon en la Baja Edad Media para proteger sus privilegios frente a los abusos concejiles, véase, por ejemplo, López Gómez, Ó.: “Clérigos, canónigos y gobernantes. Disposiciones 
en sede vacante- y confirmado por los sucesivos arzobispos compostelanos, según el cual todo individuo que injuriase verbalmente a un capitular era inmediatamente excomulgado, debiendo dar satisfacción ante el cabildo, pues, en caso contrario, dos de sus miembros pignorarían sus bienes o avales hasta el juicio, salvo en caso de que la afrenta implicase la toma de bienes, hombres o serviciales de capitulares o la usurpación de sus cotos o prestimonios, en que directamente serían tomados sus bienes sin juicio y sin apelación posible ${ }^{14}$.

Pero no solo gozaban de un especial fuero eclesiástico, sino que, además, desde el pontificado de Juan Arias en la segunda mitad del siglo XIII, el cabildo fue adquiriendo una autonomía que, a la altura del siglo XV, significaría su exención de la jurisdicción arzobispal en lo que al funcionamiento interno de la catedral y su personal se refiere, incluyendo, en la práctica, el no estar sometido al derecho canónico de visita pastoral de los prelados con la función correctiva que suponía; además, el cabildo contaba con la protección especial de un juez conservador diputado por la Santa Sede para velar por sus intereses y los de sus miembros, y, desde 1325, los canónigos y personas de la catedral estaban exentos de pagar cualquier tasa por causas vistas en el tribunal y cancillería arzobispales ${ }^{15}$.

Las constituciones y estatutos capitulares, acordados colegiadamente en las sesiones capitulares y habitualmente refrendados por sus prelados, se ocupan, entre otras cosas, de regular el gobierno de la iglesia (reuniones capitulares, cargos y oficios) y el servicio del coro y del altar (aspecto y vestimenta, ceremonial, composición y orden, residencia en el coro), estableciendo las penas por incumplir las normas, que, salvo casos graves (excomunión), normalmente son de carácter económico (multas, descuentos), y afectan a los miembros del cabildo, pero también al resto de la clerecía y personal seglar de la catedral ${ }^{16}$. Y no solo es la corporación reunida capitularmente la que juzga y sanciona, sino que algunos de sus miembros también participan individualmente en ese marco correctivo y punitivo ejerciendo determinadas funciones u oficios: los más destacados son, sin duda alguna, el deán, que, como presidente del cabildo, debía garantizar el orden en las reuniones capitulares y el cumplimiento de sus acuerdos, mandando ejecutar las penas contra los que no los guardasen; y el chantre, que, como presidente del coro, debía garantizar el orden en el coro y el normal desarrollo de los oficios divinos, corrigiendo, mandando ejecutar las penas establecidas e incluso imponiéndolas ${ }^{17}$.

frente al conflicto en las actas de la catedral de Toledo (1466-1510)", en Díaz Ibáñez, J. y Nieto Soria, J. M. (coords.): Iglesia, nobleza y poderes urbanos en los Reinos cristianos de la Península Ibérica durante la Edad Media, Murcia, Sociedad de Estudios Medievales, 2019, pp. 229-258.

14 Pérez Rodríguez, op. cit. (nota 2), pp. 161-164.

15 Vázquez Bertomeu, op. cit. (nota 2), pp. 49-50, 54-56, 100-101, 386-387 y 494.

16 Véanse Pérez Rodríguez, op. cit. (nota 2), pp. 89-108, 141-143 y 154-155; Vázquez Bertomeu, op. cit. (nota 2), pp. 93-96, 101-106 y 136-159; Iglesias Ortega, op. cit. (nota 6), pp. 181-280.

17 Vázquez Bertomeu, op. cit. (nota 2), pp. 80 y 82; Iglesias Ortega, op. cit. (nota 6), pp. 61-64. En ocasiones concretas, el cabildo nombraba a algunos beneficiados para ejercer su potestad sancionadora, como cuando, el 11 de enero de 1518, año de jubileo, comisionaron a los dos escrutadores de gracia que visitasen la catedral para poder punir, prender y castigar a "los penitençiarios que andasen bagamundando por la yglesia y fuera de sus syllas" y a "los clérigos que hallaren que an reçibido misa sin liçençia dellos o la tomaren sin ellos lo saber" (ACS, IG 479, Actas, Libro n ${ }^{\circ}$ 5, fol. 219v; cit. en López Ferreiro, op. cit. (nota 3), p. 425). 


\section{Corrección y punición de delitos: $O$ beate jacobe}

Aparte de los arbitrajes - procedimientos extrajudiciales que permitían a los miembros del cabildo resolver conflictos internos mediante el nombramiento de homes boos $^{18}$-, los actos de jurisdicción capitular que versan sobre delitos que atentan directamente contra la convivencia y el principio de hermanamiento que preside la vida capitular van más allá de la simple ejecución de penas contra faltas que afectan al patrimonio de la Iglesia, al funcionamiento interno de la catedral o al ejercicio de las obligaciones inherentes a sus cargos y beneficios ${ }^{19}$. Sobre estas cuestiones y los actos disciplinarios que contra ellas se ejecutaban son numerosas las referencias, tanto en las constituciones capitulares como en las actas capitulares: asistencia, orden y secreto de las reuniones capitulares, anuncio de las horas canónicas mediante el tañimiento de campanas, aspecto y vestimenta en la iglesia y coro, ceremonial al entrar en la iglesia y en el coro, orden y composición en el coro, prohibición de salir del coro, silencio y quietud, orden en el canto, ceremonial y orden en las misas y horas, ceremonial y orden en las procesiones y fiestas más solemnes, residencia y absentismo ${ }^{20}$, correcta gestión de las tenencia y del patrimonio capitular ${ }^{21} \ldots$

Hasta la segunda mitad del siglo XV no conocemos bien los mecanismos de corrección y castigo de dichos delitos, más allá de las disposiciones que en las constituciones capitulares del arzobispo don Juan Arias de 1255 sancionan las faltas relacionadas con el buen orden en el coro y cabildo ${ }^{22}$, que se encuadran en el conjunto de disposiciones sinodales y estatutarias inspiradas en el ideal de disciplina monástica asumido por el IV Concilio de Letrán ${ }^{23}$. El 9 de agosto de 1465 se acuerda capitularmente, con aprobación del provisor, la "Ordenança que falen cortésmente en cabildo e non se desonrren os benefiçiados" ${ }^{24}$, más conocida por estatuto de Beate Jacobe. Según esta,

por quanto alguas personas, canonigos e benefiçiados con ynpetu e anymo forioso ynjuriauan huus aos outros palabras desonestas, o qual era contra toda honestidad

18 Esta vía suele emplearse para diferencias de carácter patrimonial o económico entre beneficiados, pero también hay casos de injurias, como la que, por auto del 2 de abril de 1499, decía haber recibido el bachiller Gonzalo de Jaén, canónigo, del bachiller Gómez de Requexo, pincerna, los cuales nombraron hombres buenos al canónigo Azpeitia y al maestrescuela, respectivamente, para juzgar la causa, obligándose por sus bienes a aceptar su sentencia (ACS, IG 477, Actas, Libro n 3, fol. 168).

19 Vázquez Bertomeu, op. cit. (nota 2), pp. 129-130 y 535-536. Los acuerdos y referencias a este tipo de actos disciplinarios en las actas capitulares son continuas, pero serán objeto de otro estudio.

20 Para el siglo XVI, véase Iglesias Ortega, op. cit. (nota 6), pp. 182-194 y 240-280.

21 Constituciones establecidas, por el Illustrissimo, y Reuerendissimo Señor don Francisco Blanco, Arçobispo de Santiago, iuntamente con los Illustres Señores Dean y cabildo de la dicha sancta Iglesia, y con su consentimiento, para el buen gouierno de ella, ansi en lo que toca al seruicio del Altar y Coro, y oficios de los Prebendados, y otros ministros, como al cabildo, y conseruacion de la hazienda de la mesa capitular, Santiago, s.n., 1578, pp. 70-78.

22 Pérez Rodríguez, op. cit. (nota 2), pp. 90 y 154.

23 Véase Guijarro, S.: "The Monastic Ideal of Discipline and the Making of Clerical Rules in Late Medieval Castile”, Journal of Medieval Monastic Studies, 2 (2013), pp. 131-150. Sobre los mandatos sinodales de los arzobispos compostelanos pretridentinos al respecto de la formación y tenor de la vida del clero, véase Pérez López, S. L.: La Iglesia en la Galicia bajomedieval (1215-1563), Santiago de Compostela, Instituto Teológico Compostelano, 2003, pp. 155-236.

24 ACS, IG 475, Actas, Libro n ${ }^{\circ}$ 1, fol. 3; traslado notarial del auto anterior, Santiago, 30 de junio de 1572, ACS, P 54, Protocolos Notariales, fol. 566; cit. en López Ferreiro, op. cit. (nota 5), pp. 325-326, n. 1. 
e costituiçoons e boos usos e costumes do dito cabildo e igleia, que qualquer que non fose onesto e cortés contra o tal benefiçiado, con que ouvese questión e debate, que por ese mesmo feito pagase a pena que por cabildo fose acordado, ou por dous benefiçiados que por los ditos señores fosen deputados. Dizendo con o tal benefiçiado que asi caese na pena huun $O$ Beate Jacobe ${ }^{25}$.

Según Vázquez Bertomeu, "no quiere decir esto que no existiesen hasta entonces conductas escandalosas, sino que quizás la autoridad del deán y su vicario sea suficientemente reconocida y acatada en este aspecto"26. El hecho de que el propio estatuto refiera que las injurias iban contra las constituciones, buenos usos y costumbres del cabildo puede ser indicativo de que este último ejerciese colegiadamente dicha potestad mucho antes, como más adelante comprobaremos.

Este estatuto se completa con un auto del 30 de marzo de 1467, por el que el cabildo, después de jurar el secreto capitular, refuerza su conciencia de grupo, estableciendo que "se dano alguno ou desonor for feito a cada un dos ditos benefiçiados ou notario, que eles todos e cada un deles tornaran por elo, como se fose feyto aa persona de cada un deles e por elo tornaría cada un en singular e todos en general" ${ }^{27}$; y por otro estatuto del 4 de julio de 1468, por el que se ordenaba, so pena de ocho días de descuento, que ningún beneficiado pudiese demandar a otro cualquier deuda o injuria ante juez competente, sin que antes

requira ao benefiçiado que lle for obligado diante dous ou tres benefiçiados que lle plaza fazer de sy justiçia; e non ho querendo fazer, que o dito benefiçiado se qeyxe en pleno cabildo, e asy, dada sua qeyxa en cabildo e lle non fezeren justiçia, que posa demandar diante qualquer juiz ${ }^{28}$.

El 4 de abril de 1471 se perfila el estatuto de Beate Jacobe: "por quanto dentro eno dito cabildo e eno coro da dita ygleia se ynjuriauan de palabras orrerosas e desonestas os ditos benefiçiados huns aos outros algunas vezes sen seeren ponidos e castigados os taes delenquentes; e por evitar o sobredito", el cabildo, motu proprio, da poder al vicario del deán y a otros cuatro beneficiados para hacer una constitución y ordenanza "contra os taes benefiçiados que exçederen en dizir injuria ou palabras desonestas contra outro benefiçiado da dita ygleia, asy eno dito cabildo como eno coro, e so aquelas penas, vynculos e firmezas que a eles os ditos procuradores deputados ben visto for", otorgando contrato en firme y jurando todos sus

25 Son estas tres palabras con que comenzaba la antífona del Beate Jacobe lo único que conocemos de su letra, además de que se cantaba desde el lugar capitular hasta el altar mayor del coro. El ceremonial se puede conocer, por ejemplo, a través del siguiente caso: "La qual sentençia fue dada y pronunçiada en el dicho cabildo por votos y pareçeres de los dichos señores este dicho día, mes y año susodichos. Y, después de leyda y publicada, luego los dichos señores se llebantaron en pie y el señor cardenal Pedro Varela començó y entonó cantando la antífona $O$ Beate Jacobe, etc., y todos los dichos señores le proseguieron y cantaron hasta el cabo. Y después se dixo el verso Ora pro nobis Beate Jacobe y respondieron; y el dicho señor cardenal dixo la oratión, deziendo todo lo susodicho en prosecuçión y execuçión de la dicha sentençia" (auto de un Beate Jacobe contra el canónigo Alonso Ares del Villar, Santiago, 31 de diciembre de 1560, ACS, IG 516, Actas, Libro $\mathrm{n}^{\mathrm{o}} 16$, fols. 94v-95).

26 Vázquez Bertomeu, op. cit. (nota 2), p. 95.

27 ACS, IG 475, Actas, Libro ${ }^{\circ}$ 1, fol. $18 \mathrm{v}$.

28 Ibidem, fol. 58; traslado notarial del auto anterior realizado, Santiago, 30 de junio de 1572, ACS, P 54, Protocolos Notariales, fol. 567; cit. en López Ferreiro, op. cit. (nota 5), p. 325, n. 1. 
miembros que la cumplirían sin hacer autos contra ella y sin pedir absolución de sus penas ${ }^{29}$.

Como hemos visto, corresponde al cabildo de manera colegiada la justicia disciplinaria sobre sus miembros, valiéndose para ello de la votación en cabildo o de la sentencia, dictamen y/o pesquisas de dos beneficiados específicamente diputados para ello, que desde al menos 1501 se corresponderán normalmente a los dos escrutadores de gracia y justicia, y desde 1511 a los dos escrutadores de justicia o jueces escrutadores, oficiales elegidos cada dos de agosto entre las dignidades y canónigos para recibir las informaciones conducentes a la formación de alguna causa sobre la que el cabildo tuviese jurisdicción ${ }^{30}$. En otras catedrales también existieron jueces con funciones parecidas o incluso más amplias ${ }^{31}$.

La plasmación del estatuto de Beate Jacobe en la segunda mitad del siglo XV hay que entenderla como consecuencia del contexto bajomedieval: tras el tumultuoso siglo XIV, el cabildo compostelano se halla inmerso en una crisis económica y creciente conflictividad social que se prolonga a lo largo de la siguiente centuria, cuyos principales actores son los arzobispos, los nobles y caballeros de la Tierra de Santiago, y los concejos, especialmente el compostelano, de tal manera que, bien porque los prelados ceden parcelas de poder al cabildo para mantener su apoyo en medio de esos conflictos, bien porque este último se aprovecha de la debilidad, ausencias o vacantes de aquellos para fortalecer su independencia y normalizar la vida capitular, va adquiriendo una autonomía creciente. Precisamente en 1464 llega un nuevo prelado, Alonso de Fonseca II, con una política centralizadora y belicosa, con la que pretende recuperar el señorío de la Tierra de Santiago, en manos del pertiguero mayor Bernal Yáñez de Moscoso, y controlar a su cabildo, que se enfrenta a aquel para defender sus prerrogativas. Sin embargo, también en el seno de la corporación se desarrolla una lucha de bandos entre los partidarios de Fonseca y los del pertiguero, que se manifiesta en frecuentes injurias verbales, lo que sin duda motiva el nacimiento del estatuto de Beate Jacobe justo un año después. Las cosas se pondrán peor con el alzamiento de los irmandiños, la guerra sucesoria castellana, la rivalidad de Fonseca con el deán Diego de Muros y los enfrentamientos con el gobernador y audiencia del reino de Galicia ${ }^{32}$.

29 ACS, IG 475, Actas, Libro n ${ }^{\circ}$ 1, fol. 99; cit. en López Ferreiro, op. cit. (nota 5), p. 325.

30 Iglesias Ortega, op. cit. (nota 6), p. 221. Parece que inicialmente las pesquisas quedaban a cargo de las partes implicadas y, a vista de ellas, el cabildo votaba y dictaba sentencia (auto de jurisdicción, Santiago, 25 de junio de 1468, ACS, IG 475, Actas, Libro $n^{\circ}$ 1, fols. 55v-56; traslado notarial del auto anterior, Santiago, 30 de junio de 1572, ACS, P 54, Protocolos Notariales, fol. 566v; cit. en López Ferreiro, op. cit. (nota 5), p. 326). La referencia más antigua que he localizado de una información diputada por el cabildo sobre palabras descomedidas fue la que cometieron al bachiller Juan Paz y al arcediano de Montenegro, canónigos, en 1496 (auto de jurisdicción, Santiago, 14 de abril de 1496, ACS, IG 477, Actas, Libro n ${ }^{\circ} 3$, fol. 36). La sentencia de escrutadores sobre lo mismo más antigua que he localizado es de 1504 (auto de jurisdicción, Santiago, 16 de abril de 1504, ibidem, fol. 400v).

31 Por ejemplo, los jueces de las Cuatro Témporas en Burgos (Díaz Ibáñez, J.: "La potestad jurisdiccional del obispo y cabildo catedralicio burgalés durante el siglo XV”, Medievalismo, 22 (2012), pp. 75-97) o los jueces adjuntos en Zamora (Rico Callado, F. L.: "Violencia y justicia en Zamora: un estudio sobre los comportamientos del personal del cabildo catedralicio en época pretridentina (1532-1565)", Cuadernos de Historia Moderna, 44-1 (2009), p. 10) o Canarias (Quintana Andrés, P. C.: A Dios rogando, y con el mazo dando. Fe, poder y jerarquía en la Iglesia canaria (El Cabildo Catedral de Canarias entre 1483-1820), Las Palmas de Gran Canaria, Cabildo de Gran Canaria, 2003, pp. 181-184).

32 Véanse Vázquez Bertomeu, op. cit. (nota 2), pp. 49-57; García Oro, J.: Os Fonseca na Galicia do Renacemento. Da guerra ó mecenado. Estudio e colección documental, Noia, Toxosoutos, 2000, pp. 13-26. 
Ese mismo contexto, con las particularidades de cada diócesis y territorio, es el que explica que surjan o se reformen estatutos y/o costumbres semejantes en otras catedrales durante las últimas décadas del siglo XIV y, sobre todo, a lo largo del siglo XV: Toledo (1357, confirmada en 1491) ${ }^{33}$, Salamanca (ya en $1378^{34}$, confirmado ca. $1456^{35}$ y modificado en $1497^{36}$ ), León (1410 y 1431 , modificadas en 1454$)^{37}$, Palencia $(1423)^{38}$, Mondoñedo $(1427)^{39}$, Badajoz (antes de 1445, modificado en 1500$)^{40}$, Burgos $(1452)^{41}$, Sigüenza $(1454)^{42}$, Coria (antes de 1472) $)^{43}$, Cuenca (antes de 1495$)^{44} \mathrm{o} \mathrm{Ca}-$ narias $(1483)^{45}$; en otras diócesis las compilaciones serían más tardías (por ejemplo, en Córdoba, en $\left.1577^{46}\right)$.

\section{Conflictividad jurisdiccional arzobispo-cabildo}

Desde el punto de vista jurisdiccional, el siglo XVI también refleja una tensa relación entre el arzobispo compostelano y su cabildo, en la que el primero trata de imponer su autoridad y el segundo intenta mantener su estatus por todos los medios ${ }^{47}$. Con el arzobispo Alonso de Fonseca III se realiza por primera vez visita pastoral de la catedral, otorga constituciones sinodales y unas constituciones capitulares (15111512), que reformaban el servicio del coro y altar. En ellas no se dilucida nada nuevo sobre su potestad disciplinaria, aparte de fijar el papel correctivo del chantre dentro del coro o el del deán o su vicario como ejecutores de las penas, pero, en todo caso,

33 Lop Otín, M $\mathrm{M}^{\mathrm{a}} \mathrm{J}$ : El cabildo catedralicio de Toledo en el siglo XV: aspectos institucionales y sociológicos, Madrid, Fundación Ramón Areces, 2003, pp. 263 y 482.

34 Vicente Baz, R.: Los libros de actas capitulares de la catedral de Salamanca (1289-1489), Salamanca, Cabildo Catedral de Salamanca, 2008, p. 152.

35 Agradezco la fecha a Pedro Gómez, técnico del Archivo Catedralicio de Salamanca.

36 Rico Callado, F. L.: "Las atribuciones judiciales de los cabildos catedralicios en época moderna. Conflictos y faltas de los capitulares en Salamanca: siglos XVI-XVII", Hispania Sacra, LXXI, 143 (ene-jun. 2019), p. 237.

37 Villacorta Rodríguez, T.: El cabildo catedral de León. Estudio histórico-jurídico, siglos XII-XIX, León, Centro de Estudios e Investigación "San Isidoro", Caja de Ahorros y Monte de Piedad de León, Archivo Histórico Diocesano, 1974, pp. 323 y 328-330

38 Carbajal Ibáñez, T.: “El estatuto capitular de corrección y punición”, Publicaciones de la Institución Tello Téllez de Meneses, 59 (1989), pp. 525-543.

39 Cal Pardo, E.: Catálogo de los documentos medievales, escritos en pergamino, del Archivo de la Catedral de Mondoñedo (871-1492), Lugo, Diputación Provincial, 1990, p.545.

40 Rico Callado, F. L.: "Ruidos y rencillas en la catedral. Las faltas de los beneficiados y la jurisdicción disciplinaria del cabildo catedralicio de Badajoz en época pretridentina”, Cauriensia, 10 (2015), pp. 409-435.

41 Guijarro González, S.: "Disciplina clerical y control social en la Castilla medieval: el estatuto de corrección y punición del cabildo catedralicio de Burgos (1452)", en Arízaga Bolumburu, B. y otros (eds.): Mundos medievales: espacios, sociedades y poder, Santander, Universidad de Cantabria, 2002, vol. 2, pp. 1453-1466.

42 Portilla González, A.: Cultura, poder y redes sociales en la Castilla medieval: el clero del cabildo de la catedral de Sigüenza durante la Baja Edad Media (ss. XIV-XV), Santander, Universidad de Cantabria, 2019, pp. 215-216.

43 Cotano Olivera, F.: "Los estatutos capitulares de la Iglesia de Coria (1586)", Cauriensia, 4 (2009), p. 463 , n. 7.

44 Díaz Ibáñez, J.: La Iglesia de Cuenca en la Edad Media (siglos XII-XV). Estructura institucional y relaciones de poder, Madrid, Universidad Complutense de Madrid, 1996, p. 846.

45 Quintana Andrés, op. cit. (nota 30), p. 181.

46 Vázquez Lesmes, R.: Córdoba y su cabildo catedralicio en la Modernidad, Córdoba, Publicaciones del Monte de Piedad y Caja de Ahorros de Córdoba, 1987, pp. 123-124.

47 Es algo que se repite en prácticamente en todas las catedrales españolas (véase, por ejemplo, Rico Callado, op. cit. (nota 36), pp. 233-239). 
sabemos que el cabildo realizó diligencias o litigó ante Su Santidad contra las tres cosas: visita, sinodales y capitulares ${ }^{48}$.

Bajo su sucesor, Juan Tavera, se solicita al papa el nombramiento de juez conservador que tratase sobre los agravios cometidos por los arzobispos contra su cabildo, entre ellos, su pretensión de despojarle de su condominio señorial, de la exención de que gozaban los familiares de los capitulares de no ser castigados sino por los jueces ordinarios, de la facultad que tenían los dos escrutadores para corregir y castigar las faltas y excesos cometidos por los beneficiados de la catedral, etc. El prelado fue emplazado para comparecer en Roma (1526), pero seguramente la cosa quedó en nada por intermediación de la Corona ${ }^{49}$. No parece casualidad que sea en 1527 cuando figure por primera vez en un proceso de Beate Jacobe la expresión "usando con él de beninidad e fratenal curreçión, conforme a sus costituçiones e laudabele costunbre en que están de ponyr y castigar los semejantes casos" ${ }^{\circ 0}$. A partir de entonces se hace muy frecuente, probablemente para reforzar dicha potestad capitular. El 28 de enero de 1544, el provisor dicta sentencia en favor del canónigo Juan Álvarez Lucero contra su cabildo, el cual apeló ante el papa la prohibición que impuso dicho provisor "de la possesyón de corregirse a los benefiçiados que delinquen en el cabildo y en esta santa Yglesia" 51 .

El Concilio de Trento y los concilios provinciales derivados del mismo suponen una viraje decisivo en las combativas relaciones entre cabildos y obispos, pero no dejan contentos ni a unos ni a otros, los cuales, a pesar de todo, firman las concordias sobre los concilios provinciales castellanos en 1567 -el arzobispo compostelano Gaspar de Zúñiga fue uno de los contrarios al acuerdo-, siendo confirmadas dos años después por breve pontificio, momento a partir del cual se continuarán las disputas en el marco particular de cada diócesis y no en el colectivo de la Congregación de Castilla y de los concilios, empleando los cabildos una estrategia defensiva consistente en transformar cuestiones de disciplina eclesiástica y de reforma moral del clero en conflictos de jurisdicción entre la Corona-que apoya el fortalecimiento de los prelados-y el Papado - que utiliza los cabildos para contrarrestar el control de la Iglesia hispánica por la Corona $-^{52}$.

Las materias jurisdiccionales que fueron objeto de mayor contienda en Santiago se refieren a los derechos episcopales de visitar y juzgar a su cabildo. Así, por ejemplo, el 17 de marzo de 1555 -en medio de la discusión sobre la aplicación del canon 4 de la sesión VI del Concilio de Trento-, la corporación acuerda apelar ante $\mathrm{Su}$ Santidad de cualquier mandato que el prelado Juan Álvarez de Toledo realizase contra aquella en relación a la facultad que el obispo auxiliar y visitador arzobispal, magistral Bernardino Carmona, pretendía tener de visitar al cabildo y beneficiados

\footnotetext{
López Ferreiro, op. cit. (nota 3), pp. 13-17.

Ibidem, pp. 87-88.
}

50 Auto de Beate Jacobe contra el canónigo cardenal Jácome Alonso de Puga "el Viejo", Santiago, 24 de diciembre de 1527, ACS, IG 284, Jurisdicción del Cabildo. Procesos varios, ejecutorias, breves y autos sobre el Beate Iacobe, "Documentos sobre el Beate Jacobe y otros referentes a la jurisdicción del Cabildo", fol. 1-1v.

51 ACS, IG 512, Actas, Libro n 12, fol. 172-172v.

52 Véase Fernández Terricabras, I.: Felipe II y el clero secular. La aplicación del concilio de Trento, Madrid, Sociedad Estatal para la Conmemoración de los Centenarios de Felipe II y Carlos V, 2000, pp. 291-359 y 367-373. Sobre la lenta aplicación de la reforma tridentina en la diócesis compostelana, iniciada por el arzobispo Gaspar de Zúñiga, véase Rey Castelao, O.: "La Iglesia gallega en tiempos de Felipe II: la aplicación del Concilio de Trento”, en Martínez Millán, J. (dir.): Felipe II (1527-1598): Europa y la monarquía católica, Madrid, Parteluz, 1998, pp. 341 y ss. 
de la catedral contradiciendo la visita personal de los obispos decretada por el Sacro Concilio y prescrita por costumbre antigua del cabildo ${ }^{53}$. Será su sucesor, Gaspar de Zúñiga y Avellaneda, el que visite personalmente su iglesia metropolitana, resultando de ella unas constituciones capitulares (1569), reproducidas casi literalmente por las de Francisco Blanco de Salcedo (1578), las cuales, a la postre, permanecerían en vigor durante todo el Antiguo Régimen. En ninguna de ellas se trata sobre el espinoso asunto de la jurisdicción capitular del Beate Jacobe.

No es casualidad que el 16 de agosto de 1549, a tenor de una sentencia de Beate Jacobe contra dos canónigos que habían tenido malas palabras en cabildo y porque convenía al derecho del cabildo que constase la jurisdicción, uso y costumbre inmemorial que tenía de corregir y castigar los delitos y excesos acaecidos entre los beneficiados y personas del "cauildo, coro, iglesia y términos della (...), en vista haz e paz de los perlados que avían seydo en la dicha santa iglesia e de sus ofiçiales de executar las sentençias dadas por el dicho cabildo contra los tales beneficiados y otras personas delinquentes", el procurador capitular pidiese al capítulo que mandase sacar información de dicha jurisdicción "y se la mandasen dar en pública forma, en manera que haga fee para conserbaçion del derecho de sus partes". Para ello fueron escogidos cuatro testigos cualificados por el rango de su prebenda (todos eran dignidades) y su antigüedad como prebendados (entre 19 y más de 40 años), los cuales confirmaron bajo juramento que se venía ejerciendo sin impedimento ni contradicción de los arzobispos ni de sus provisores - presentes en muchas de dichas sesiones capitulares-, dando diversos ejemplos que recordaban o habían oído de otros capitulares más antiguos, ya fallecidos. Juan Rodríguez de Ulloa declaró incluso que había visto y leído en los archivos del Tesoro y en otros lugares donde se guardaban los libros antiguos del cabildo muchos autos de prisiones y sentencias -algunos de hacía más de 120 años, lo que prueba que se practicaban antes del estatuto de 1465-, dados por el cabildo y sus escrutadores contra las personas y beneficiados que reñían, constando en ellos que en algunos casos se les prendía y encarcelaba en diversos lugares (en sus propias casas, en las de otros beneficiados, en los monasterios compostelanos de Santa María a Nova y Santa María de Sar, o en los de San Xoán da Cova y San Lourenzo de Carboeiro) ${ }^{54}$.

Precisamente en el último día de dicho año, el provisor del arzobispado de Santiago se opuso por vez primera al ejercicio de dicha jurisdicción por parte del cabildo, iniciándose un importante pleito que acabó reforzando la misma. En auto capitular de ese día se sentenció contra el racionero Alonso Fariña y el capellán del coro Leonel Feijoo por cierta rencilla que habían tenido en el coro el día anterior, pero, como esa misma noche el racionero, encapuchado y armado, le había atacado con golpes y porrazos en la plaza del Campo -actual plaza de Cervantes-, el provisor Peña, entendiendo que le pertenecía la causa, se querelló contra el cabildo a través del fiscal arzobispal, encarcelando a su vicario capitular y al escrutador de justicia en las bóvedas de la catedral, y a los dos beneficiados pendencieros en la "torre de la plaza" - cárcel pública del arzobispo-. Como el provisor, amparándose en el Concilio de Trento, rechazó la apelación capitular ante la Santa Sede, interpusieron querella de fuerza contra él y el fiscal ante la Real Audiencia de Galicia (4 de enero de 1550), la cual dictó provisión seis días después para que el provisor exhibiese el proceso ori-

53 ACS, IG 515, Actas, Libro n 15, fols. 168v-169; cit. en López Ferreiro, op. cit. (nota 3), pp. 129-130.

54 ACS, IG 715, Tomos de Varia, Segunda serie, t. III, doc. 199dup., fols. 1-8v. 
ginal y admitiese la apelación, soltase a los canónigos y les absolviera de cualquier pena impuesta, incluida la excomunión; el provisor apeló ante el Rey y su Consejo, pidiendo sobrecarta, ante la cual volvió a apelar, pero se le volvió a notificar una tercera provisión para que cumpliese la primera. Ante su negativa, se mandó secuestrar sus bienes temporales y desterrarlo del reino y, estando el 15 de enero en Pontevedra a punto de partir, enterado del fallecimiento siete días antes en Valladolid del arzobispo Pedro Manuel, otorgó una petición por la que aceptaba la apelación capitular, absolvía y mandaba soltar a los presos. Finalmente, el cabildo obtuvo ejecutoria (16 de abril) y breve de Julio III ( 28 de abril) favorables a su causa ${ }^{55}$.

Otro conflicto sobre dicha jurisdicción se produjo el 9 de junio de 1572, al respecto de una cuestión de violencia verbal en la catedral por parte del canónigo Lope Ochoa de Avellaneda contra el cantor Luis de Cardona, en la que el deán don Baltasar López Gallo, tío del primero, ejerció también violencia física contra aquel. Notificada la sentencia del cabildo contra el deán, este respondió que era nula por no tener el cabildo facultad para castigarle y por haber actuado en cumplimiento de la suya propia ${ }^{56}$. Una semana después presentó una petición al cabildo, argumentando que no podían juzgarle por ser él juez junto con aquel en ese tipo de autos y no podían ser ellos jueces de un juez, como nunca había así ocurrido y menos sin oírle ni citarle previamente, por lo que apelaba ante cualesquier instancias superiores y protestaba el auxilio real de la fuerza y $\operatorname{costas}^{57}$. Para sostener su defensa, el cabildo pidió al provisor que ordenase a Gonzalo de Reguera, notario del número y cabildo, sacar de los libros de actas capitulares traslado de los autos y condenas contra beneficiados que eran desobedientes en cabildo. El provisor ordenó hacerlo, previa citación de las partes y unos días después se acometió. El pleito siguió ante la audiencia arzobispal ${ }^{58}$.

$\mathrm{Al}$ asumir la jurisdicción criminal contra sus beneficiados en sede vacante, el cabildo participa más directamente en determinados delitos, como el que aconteció la noche de Navidad de 1573 en la catedral entre algunas personas eclesiásticas y seglares, dando plenos poderes a sus provisores sede vacante para juzgar en dichos delitos con que consultasen al cabildo antes de dictar sentencia ${ }^{59}$.

55 ACS, IG 284, Jurisdicción del Cabildo. Procesos varios, ejecutorias, breves y autos sobre el Beate Iacobe, "Documentos sobre el Beate Jacobe y otros referentes a la jurisdicción del Cabildo", fols. 43-61v. Por auto del 27 de junio de 1572 se manda guardar dicha ejecutoria en el archivo catedralicio (ACS, IG 517, Actas, Libro ${ }^{\circ} 17$, fol. 108v).

56 ACS, IG 715, Tomos de Varia, Segunda serie, t. III, doc. 199dup., fol. 20.

57 Ibidem, fols. 23-24v.

58 Petición del escribano Gonzalo de Morou, en nombre del cabildo al provisor para sacar traslado de los autos de Beate Jacobe, Santiago, 20 de junio de 1572, ACS, P 54, Protocolos Notariales, fol. 564-564v; notificación del auto del provisor al deán y traslado de los autos citados, Santiago, 30 de junio de 1572, ibidem, fol. 565 y ss.; poder del deán a Gonzalo Fernández, procurador de causas en la audiencia, para seguir pleito sobre lo mismo, Santiago, 4 de julio de 1572, ibidem, fol. 716; cit. en López Ferreiro, op. cit. (nota 3), p. 135. El 2 de diciembre de 1583, el notario capitular Domingo Cabaleiro entregó al cabildo las informaciones y averiguaciones que se habían hecho contra los beneficiados y ministros de la catedral que habían delinquido en ella para guardarlas en el archivo (ACS, IG 518, Actas, Libro n 18, fol. 540-540v).

59 ACS, IG 517, Actas, Libro n ${ }^{\circ}$ 17, fols. 223v-224. Un caso semejante en un auto del 30 de julio de 1534 en que ratifican la información tomada por Lope Sanchez, vicario sede vacante, contra el canónigo Gómez Rodríguez, por cierto delito cometido contra el tondidor compostelano Pedro de Piñeiro, dando poder a aquel "para que pueda conosçer y conosca de quales quiera delitos e cabsas creminales que ayan subçedido e suvçedyeren de aquí en delante durante la dicha sede vacante contra qualesquiera benefiçiados desta dicha santa Yglesia" (ACS, IG 484, Actas, Libro n 10, fol. 124-124v). 
Un nuevo conflicto entre el arzobispo y su cabildo se produce el 19 de abril de 1586 al pretender juzgar este último una causa sobre una rencilla sucedida en el coro entre los canónigos Domingo Blanco de Caviedes y Pedro Yáñez, maestro de capilla, lo que motivó que se volviese a presentar ante aquel por parte del abogado del cabildo la ejecutoria y demás autos de la jurisdicción capitular para defenderla en un nuevo pleito ${ }^{60}$. Dos años después (12 de abril de 1588) otra sentencia posiblemente discutida motiva que el deán propusiese un cabildo pleno para la defensa de la jurisdicción correctiva y punitiva del cabildo, y que, tras el respaldo de la votación, se nombrase una comisión para tratar las diligencias que habían de hacerse para conservarla ${ }^{61}$.

En 1591, vuelve a aparecer un nuevo auto de prisión dado por el provisor contra el deán y el escrutador de justicia que recibió la información sobre cierta pendencia inter coros entre el organista Isasi y el racionero Cordero, por considerar que se vulneraba la jurisdicción arzobispal, con la consiguiente movilización del arsenal jurídico del cabildo para defender la suya ante Su Señoría ${ }^{62}$.

En 1597, con motivo de un Beate Jacobe lanzado contra el provisor y canónigo cardenal Juan de Landeras, se produjo una contraofensiva judicial por parte del arzobispo Juan de San Clemente, que acabó con el apresamiento de varios capitulares y la intermediación del capitán general del reino y gobernador de la Real Audiencia de Galicia para alcanzar una concordia duradera, firmada por ambas partes el 25 de junio. En ella se acordaron dos puntos: por un lado, que la carcelería de las dignidades, prebendados y canónigos de la catedral compostelana fuese en el cuarto nuevo o torre de la misma, poniendo el prelado "las prissiones y guardas que le pareziere conforme a la calidad y grauedad del delito"63, excepto que este fuese de tal gravedad (homicidio, adulterio o semejante) que mereciese pena de muerte, degradación o deposición, en que sería la cárcel pública del arzobispado; por otro, que el cabildo usase y ejerciese la jurisdicción de multar y penar a los prebendados y personas eclesiásticas de la catedral mediante el auto de Beate Jacobe conforme a la calidad y gravedad del delito, procediendo sumaria y ejecutivamente en virtud de la información recibida, "con que fuese por culpas y excessos cometidos dentro de las puertas de dicha santa yglessia y saluo el derecho de preuención del señor Arcobispo o su prouisor". Como aconteció en muchos otros cabildos hispánicos, la conflictividad episcopocapitular continuó siendo una constante en la siguiente centuria $^{64}$. Dicha concordia, confirmada por el cabildo y el arzobispo Maximiliano

60 ACS, IG 519, Actas, Libro n ${ }^{\circ}$ 19, fol. 161-161v.

61 Ibidem, fol. 359-359v.

62 Autos sobre jurisdicción capitular, Santiago, 8-11 de enero de 1591, ACS, IG 557, Actas, Libro n ${ }^{\circ} 20$, fols. 72v74; cit. en López Ferreiro, op. cit. (nota 3), pp. 339-341.

63 Véase, por ejemplo, un auto por el que el canónigo D. Baltasar de Sandoval apelaba ante Su Santidad contra su apresamiento en el cuarto nuevo por el provisor debido a un caso de estupro, Santiago, 20 de julio de 1598, ACS, P 119/3, Protocolos Notariales, fols. 105-106v.

64 Aparte de los ya citados, véanse Callado Estela, E.: "De obispos y cabildos valencianos. Conflictividad episcopocapitular en Segorbe durante el siglo XVII", en Callado Estela, E. (ed.): Gloria, alabanza y poder. Cabildos catedrales hispánicos en la Época Moderna, Madrid, Sílex Ediciones, 2021, pp. 117-163; ídem: "Los desórdenes del canónigo de la Catedral de Orihuela José Llop. Reforma, delitos y castigo en el siglo XVII", Studia Historia. Historia Moderna, 42:1 (2020), pp. 329-349; Coello de la Rosa, A.: "Conflictividad capitular y poderes locales en el Cabildo de Manila (1690-1697)", Colonial Latin American Review, 25:3 (2016), pp. 331336; Corada Alonso, A.: "Las visitas pastorales como medio para la reformación del clero capitular. Un ejemplo de la archidiócesis de Burgos”, en Martín García, A. y Pérez Álvarez, Ma J. (coords.): Religiosidad y Reforma 
de Austria en $1608^{65}$, fue modificada por otra del 12 de septiembre de 1651, por la que el arzobispo Fernando de Andrade y Sotomayor y su cabildo acordaron que la carcelería que se aplicase a los racioneros fuese en otro lugar de la catedral distinto al de dignidades y canónigos, y que el auto de Beate Jacobe se ejecutase sin efecto suspensivo, a pesar de existir apelación y hasta que se resolviese, pero, en cuanto al efecto devolutivo, sí pudiese apelarse ante el arzobispo en persona o, en su ausencia, ante el provisor que fuese al mismo tiempo gobernador en lo espiritual del arzobispado $^{66}$. Tras varios años de litigios y conferencias entre ambas partes, el 31 de mayo de 1679 fueron expedidas por la Sacra Rota unas ejecutoriales apostólicas de Inocencio XI, en virtud de las cuales se mantuvo y amparó al cabildo en la posesión y costumbre de conocer de los reos eclesiásticos de cualquier jerarquía, castigarlos y punirlos con penas pecuniarias, cárcel y más correspondiente, con tal que cometieran delito dentro de dicha santa iglesia y sus ámbitos, inhibiendo al arzobispo y su provisor del conocimiento de esas causas, mientras estuviera conociendo de ellas el deán o su vicario ${ }^{67}$. Aún en 1831 se registra un litigio ante el Tribunal de la Rota sobre competencia de jurisdicción entre cabildo y Arzobispo en el conocimiento de una causa formada contra el canónigo cardenal Manuel Ventura de Fraga por insultos al maestro de ceremonias ${ }^{68}$, lo que confirma que jurisdicción se mantuvo hasta la definitiva abolición de casi "todas las jurisdicciones privilegiadas y exentas" establecida en el Concordato de $1851^{69}$.

Un apunte final al respecto de las figura de los jueces adjuntos, existente en otras catedrales para juzgar conjuntamente con su obispo de los delitos, incluso los graves, cometidos por los capitulares ${ }^{70}$. A pesar de que no existían en la catedral compostelana antes de Trento, amparándose (al igual que otros cabildos hispánicos) en lo decretado por aquel, el compostelano intentó obtener de Roma el reconocimiento de dicha figura a comienzos del XVII ${ }^{71}$. El 11 de julio de 1614 se dio poder a don Fernando de

católica en el Noroeste de la península ibérica. Siglos XV-XIX, Madrid, Sílez Ediciones, 2019, pp. 197-199; Quintana Andrés, P. C.: "El cabildo catedral y el obispo Gutiérrez de Roza: poder y antagonismo en la diócesis de Canarias en el Seiscientos", Boletín Millares Carlo, 20 (2002), pp. 191-215.

65 Acuerdo capitular con el Arzobispo sobre los Beate Jacobe, Santiago, 19 de agosto de 1608, ACS, IG 560, Actas, Libro $\mathrm{n}^{\circ} 22$, fols. $469 \mathrm{v}-470$.

66 ACS, IG 713, Tomos de Varia, Primera Serie, t. I, doc. 87; véase ACS, IG 284, Jurisdicción del Cabildo. Procesos varios, ejecutorias, breves y autos sobre el Beate Iacobe, "Documentos sobre el Beate Jacobe y otros referentes a la jurisdicción del Cabildo", fols. 174-179v; cit. en López Ferreiro, op. cit. (nota 3), p. 352. Aún el 29 de enero de 1599 se nombra una diputación para "el remedio de las jurisdiçiones y de su recuperaçión" (ACS, IG 557, Actas, Libro n 20, fol. 775).

67 Testimonio de varios documentos que acreditan la jurisdicción del Cabido en conocer de las casusas que se susciten por delitos cometidos en el ámbito de la iglesia, Santiago, 31 de diciembre de 1787, ACS, IG 287, Asuntos Jurisdiccionales. Enajenación de jurisdicciones por Reales Cédulas, condominio jurisdiccional, regidoratos, etc., "Asuntos jurisdiccionales. Condominio de la jurisdicción temporal. Antecedentes varios (1772-1787)".

68 ACS, IG 284, Jurisdicción del Cabildo. Procesos varios, ejecutorias, breves y autos sobre el Beate Iacobe.

69 Gonzalo Gozalo, Á.: El cabildo de la catedral de Burgos en el siglo XIX (1808-1902), Burgos, Cabildo Metropolitano de Burgos, Caja de Ahorros del Círculo Católico y Diputación Provincial de Burgos, 1993, p. 366.

70 Véase, por ejemplo, Coello de la Rosa, A.: "El cabildo catedralicio y los jueces adjuntos en la Lima colonial (1601-1611)", Colonial Latin American Review, 20-3 (2011), pp. 331-361; Irigoyen López, A.: "Los conflictos entre obispo y cabildo catedralicio de Murcia tras el Concilio de Trento (1583-1606)", en Callado Estela, E. (ed.): Gloria, alabanza y poder. Cabildos catedrales hispánicos en la Época Moderna, Madrid, Sílex Ediciones, 2021, pp. 200-224; Rico Callado, op. cit. (nota 36), pp. 233-247; Terráneo, S.: "Los adjuntos del cabildo en la diócesis del antiguo Tucumán (1592-1699)”, Anuario Argentino de Derecho Canónico, 24 (2018), pp. 163-180.

71 Auto para tratar sobre la solicitud de adjuntos a Su Santidad, Santiago, 4 de diciembre de 1602 (ACS, IG 559, Actas, Adición al Libro $2^{\circ}$ de sede vacante, fol. 136v). 
Andrade y Sotomayor - a la postre, arzobispo compostelano- y al canónigo cardenal don Juan de Salazar, agente y procurador general en los negocios del estado eclesiástico de la Corona de Castilla y León, para emplear un crédito de 3.000 escudos de oro -que se ordenó librar al mayordomo capitular al día siguiente- en obtener la gracia de los adjuntos ${ }^{72}$. Sin embargo, una vez fracasó la tentativa, se ordenó revocar dichos poderes y crédito el 21 de enero de $1615^{73}$.

\section{Análisis de los casos registrados}

\section{Fuentes, número y evolución}

Seguimos en este epígrafe la estela de otros estudios semejantes que emplean fuentes analizables estadísticamente ${ }^{74}$. En las actas capitulares conservadas en el ACS se puede seguir un registro no sistemático ${ }^{75}$ de los actos de jurisdicción interna llevados a cabo por su cabildo contra el personal catedralicio mediante el empleo de la vía de corrección y punición establecida con los Beate Jacobe desde 1465 en adelante ${ }^{76}$-tengamos en cuenta que no se incluyen aquellos actos que emplean otras vías como las de arbitraje mediante "hombres buenos" o la aplicación directa de las penas previstas en las constituciones capitulares-. Esta fuente se complementa con un legajo de actos de jurisdicción interna del mismo $\operatorname{archivo~}^{77}$ y con algunos incluidos en protocolos notariales conservados en aquel ${ }^{78}$ y en el archivo universitario ${ }^{79}$. El marco cronológico escogido se corresponde al pontificado de los arzobispos que van desde Alonso de Fonseca II en 1464 hasta Juan de San Clemente en $1602^{80}$, casi 138 años, entre los cuales he podido identificar 170 casos, entre informaciones, sentencias y/o autos varios.

ACS, IG 191, Posesiones y vacantes de arzobispos, Libro nº 2, fol. 10.

Ibidem, fol. $91 \mathrm{v}$.

74 Aparte de los ya citados, véanse Guijarro González, S.: “Justicia eclesiástica y control social en Burgos durante el siglo XV: el castigo de las faltas y los delitos de clero en la Castilla bajomedieval", Anuario de Estudios Medievales, 46/2 (jul.-dic. 2016), pp. 787-818; Polanco Pérez, A.: "Violencia verbal en el estamento eclesiástico palentino a través de las acta capitulares durante el s. XV", Publicaciones de la Institución Tello Téllez de Meneses, 72 (2001), pp. 373-380; Irigoyen López, A.: "La difícil aplicación de Trento: las faltas de los capitulares de Murcia (1592-1622), Hispania Sacra, 62 (2010), pp. 157-179.

75 Por ejemplo, en una anotación en el segundo libro de actas capitulares se dice que "no ay en este libro ningún abto de jurisdiçiçon, eçepto que cada año nonbrauan escrutadores, donde se ynfiere que tenían jurisdiçión, pues nonbrauan quien sacase las ynformaçiones" (ACS, IG 476, Actas, Libro nº 2, fol. 5).

76 ACS, IG 475-484, 511-519, 557-558, Actas, Libros nos 1-21.

77 ACS, IG 284, Jurisdicción del Cabildo. Procesos varios, ejecutorias, breves y autos sobre el Beate Iacobe.

78 ACS, P 9, P 11, P 54, P 96 y P 100, Protocolos Notariales; ACS, IG 715, Tomos de Varia, Segunda serie, t. III, docs. 199 y 199dup.

79 Arquivo Histórico Universitario de Santiago (AHUS), S 180, S 191, S 194 y S 289, Protocolos Notariales, Santiago de Compostela.

80 Las fuentes siguen registrando casos de jurisdicción capitular interna durante toda la época moderna. Se ha elegido este marco temporal por pura conveniencia y la necesidad de marcar un límite, dada la excesiva densidad de la información a consultar. No obstante, a expensas de que estudios sobre siglos posteriores nos aporten nuevos datos, terminar el análisis a comienzos del XVII nos permitirá comprobar el efecto inicial de las reformas tridentinas. 
Gráfico $\mathrm{n}^{\circ} 1$. Evolución lineal del número de casos de jurisdicción interna

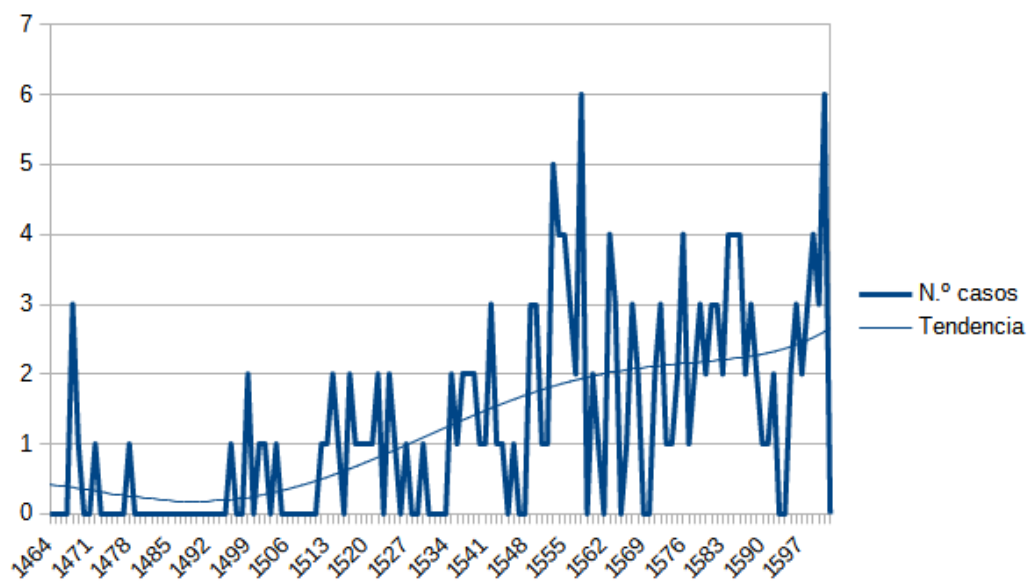

En el gráfico $\mathrm{n}^{\circ} 1$ puede apreciarse que la curva de la tendencia, después de un pequeño repunte inicial tras el establecimiento de la ordenanza del Beate Jacobe, reproduce un paulatino incremento hasta los últimos años de la década de los 60 del siglo XVI, momento en que se estabiliza y vuelve a repuntar en los últimos años de la centuria. Parece que hay una correlación del incremento de los casos de jurisdicción interna, por una parte, con la defensa de la misma frente a las injerencias del arzobispo, sobre todo a raíz del Concilio de Trento - cuya evolución hemos podido conocer con detalle en el epígrafe anterior-, y, por otra, con la aplicación de la reforma y profesionalización del clero secular, principalmente de la derivada de los preceptos tridentinos.

Esto se puede percibir más claramente a partir de la Tabla $\mathrm{n}^{\circ} 1$, que muestra el número de casos por cada prelado. La etapa con mayor número de casos tiene lugar entre los mandatos del cardenal Juan Álvarez de Toledo ${ }^{81}$ - con un total de 19- y del arzobispo Gaspar de Zúñiga y Avellaneda ${ }^{82}$-con 16 casos-, destacando incluso los habidos en la vacante entre ambos -7 casos-: en tan solo 19 años $\left(1550-1569^{83}\right)$ se produce el $25 \%$ de los habidos en los casi 138 años del período estudiado. Con los prelados siguientes se mantiene el ritmo, sobre todo con Francisco Blanco de Salcedo $^{84}$-quien favoreció los conflictos internos del cabildo mediante la masiva colo-

81 Padre tridentino, futuro candidato del emperador Carlos V para obtener el solio pontificio y claro defensor de las prerrogativas episcopales frente a los cabildos: fue uno de los cardenales que se opuso al breve Insupremo iustitia de 1555, por el que los obispos debían paralizar todas las actuaciones realizadas contra los cabildos (Fernández Terricabras, I.: "Conflictos entre Carlos V y los cabildos catedralicios de la Corona de Castilla (1552-1556)”, en Martínez Millán, J. (coord.): Carlos V y la quiebra del humanismo político en Europa (15301558), Madrid, Sociedad Estatal para la Conmemoración de los Centenarios de Felipe II y Carlos V, 2001 , vol. 2, p. 368).

82 Padre tridentino, convocante del concilio provincial compostelano en 1565 y responsable, como vimos, de la visita pastoral a su cabildo y de sus constituciones capitulares de 1569.

83 Las fechas no son casuales: de 1547 es el controvertido canon 4 de la sesión VI del Concilio, de 1550 es la ejecutoria favorable a la jurisdicción capitular y de 1569 es la aprobación de la concordia del concilio compostelano.

84 Padre tridentino, responsable de su aplicación en la diócesis en su faceta normativa -mediante la publicación de sus constituciones sinodales y capitulares-e intelectual -mediante la publicación de numerosos tratados para la instrucción de sacerdotes- (véase Rey Castelao, O: “Biografía o hagiografía? Memorias breves del arzobispo 
cación de parientes en el mismo ${ }^{85}$ - y con Alonso Velázquez; sin embargo, el récord - con 32 casos- se produce durante el pontificado de Juan de San Clemente, quien asimismo alimentaría dicha conflictividad, en este caso, introduciendo a clientes y $\operatorname{amigos}^{86}$.

Tabla $n^{0} 1$. Número de casos de jurisdicción interna por arzobispo

\begin{tabular}{|c|c|}
\hline Arzobispo & N. ${ }^{o} \operatorname{casos}$ \\
\hline Alonso de Fonseca II (1464-1507) & 12 \\
\hline Vacante (1507-1508) & 0 \\
\hline Alonso de Fonseca III (1508-1524) & 14 \\
\hline Vacante (1524) & 2 \\
\hline Juan Tavera (1524-1534) & 3 \\
\hline Vacante (1534) & 0 \\
\hline Pedro Sarmiento (1534-1541) & 11 \\
\hline Vacante (1541-1542) & 2 \\
\hline Gaspar de Ávalos (1542-1545) & 4 \\
\hline Vacante (1545-1546) & 0 \\
\hline Pedro Manuel (1546-1550) & 4 \\
\hline Vacante (1550) & 3 \\
\hline Juan Álvarez de Toledo (1550-1557) & 19 \\
\hline Vacante (1557-1559) & 7 \\
\hline Gaspar de Zúñiga (1559-1569) & 16 \\
\hline Vacante $(1569-1570)$ & 0 \\
\hline Cristóbal Fernández de Valtodano (1570-1572) & 4 \\
\hline Vacante (1572-1574) & 3 \\
\hline Francisco Blanco (1574-1581) & 13 \\
\hline Vacante (1581-1582) & 3 \\
\hline Juan de Liermo (1582-1582) & 0 \\
\hline Vacante (1582-1583) & 2 \\
\hline Alonso Velázquez (1583-1587) & 14 \\
\hline Vacante (1587) & 2 \\
\hline Juan de San Clemente (1587-1602) & 32 \\
\hline Total (1468-1602) & 170 \\
\hline
\end{tabular}

don Francisco Blanco de Salcedo", en Rey Castelao, O. (coord.): Cuatro textos. Cuatro contextos. Ensayos de historia cultural de Galicia, Santiago, 2004, pp. 13-63).

85 Véase Iglesias Ortega, A.: "Nepotismo y patronazgo eclesiástico en la Galicia moderna: el cabildo catedralicio de Santiago de Compostela”, Hispania Sacra, LXVIII, 137 (ene.-jun. 2016), p. 263.

86 Ibidem, p. 265. 


\section{Tipos de delitos}

La jurisdicción interna del cabildo compostelano incluía la normal corrección y penalización de las faltas reguladas en las constituciones capitulares sobre su patrimonio, orden interno y cumplimiento de las obligaciones profesionales, pero el tipo de delitos que analizamos aquí están relacionados fundamentalmente con las injurias (físicas, verbales y escritas) y el deshonor, aunque en muchas ocasiones venían acompañados de los anteriores. Las fuentes emplean con mucha libertad e imprecisión una amplia gama terminológica para referirse a las unas y a los otros: ademanes, altercado, atrevimiento, bullicio, cuestión, delito, defecto, desacato, descomedimiento, descomposición, desconsideración, descortesía, deshonra, desmesura, desobediencia, diferencia, escándalo, exceso (de manos), falta, incumplimiento, indecencia, injurias, irreverencia, libertad de palabras, menosprecio, mentira, murmuraciones, negocio (de liviandades), ofensa, palabras (de afrenta, de agravio, de desasosiego, de enojo, de muy poca crianza, de rencilla, de riña, desacatadas, descomedidas, descompuestas, descorteses, deshonestas, desobedientes, en perjuicio, feas, inapropiadas, indecentes, injuriosas, malsonantes, ruidosas), pendencia, perjuicio, perturbación, rencilla, riña, ruido, rumor, violación de sagrado. Todos estos términos se refieren en general a delitos de carácter leve, dado que los muy graves eran competencia del arzobispo y sus oficiales ${ }^{87}$.

Tabla $n^{\circ}$ 2. Tipos de delitos

\begin{tabular}{|c|c|c|}
\hline Tipo de delito & $\mathrm{N}^{\circ}$ & $\%$ \\
\hline $\mathrm{A}$ & 41 & 24,1 \\
\hline $\mathrm{C}$ & 39 & 22,9 \\
\hline $\mathrm{D}$ & 30 & 17,7 \\
\hline $\mathrm{A}+\mathrm{D}$ & 14 & 8,2 \\
\hline $\mathrm{C}+\mathrm{D}$ & 11 & 6,5 \\
\hline $\mathrm{E}$ & 7 & 4,1 \\
\hline $\mathrm{A}+\mathrm{B}$ & 6 & 3,5 \\
\hline $\mathrm{B}$ & 2 & 1,2 \\
\hline A+B+D & 1 & 0,6 \\
\hline Sin especificar & 19 & 11,2 \\
\hline Total & 170 & 100 \\
\hline
\end{tabular}

87 En este grupo entrarían el homicidio, el adulterio, el incesto, el concubinato público, la sodomía o la herejía. Así, por ejemplo, conocemos el caso del canónigo Juan García, quien hirió mortalmente al racionero Juan Pérez de Mondragón en 1554, por lo que fue automáticamente descomulgado y, ante la apelación de aquel a Su Santidad y la provisión de la Real Audiencia de Galicia para que aquella fuese admitida, el provisor se inhibió y el cabildo acató finalmente la sentencia absolutoria dictaminada por el juez apostólico nombrado por el nuncio (Iglesias Ortega, A.: Catálogo biográfico de la catedral de Santiago de Compostela. Dignidades, canónigos y racioneros del siglo XVI, Santiago de Compostela, Consorcio de Santiago y Universidade de Santiago de Compostela, 2019, t. I, pp. 446-449). 
A partir de ellos hemos plasmado en la tabla $\mathrm{n}^{\mathrm{0}} 2$ una clasificación tipológica de los delitos de acuerdo con la siguiente nomenclatura: A (violencia verbal), B (violencia física), C (injurias verbales y/o físicas), D (desacato y/o desobediencia), E (sacrilegio combinado con alguna/s de las anteriores). La diferencia que planteamos entre violencia e injuria es que la segunda implica un daño al honor de la persona, familia o institución, pero, a la postre, ambas son formas de violencia. En primer lugar, si descartamos las causas indeterminadas, los casos con ejercicio de violencia (sola o combinada) son mayoría absoluta $(78,8 \%)$, predominando en ellos los exclusivamente verbales $(86,9 \%)$ sobre los que incluyen violencia física $(13,1 \%)$; si distinguimos la simple violencia de las injurias, la primera presenta un mayor peso $(56,3 \%)$ sobre las segundas $(43,7 \%)$. En segundo lugar, un $38,4 \%$ de los casos registran algún tipo de desacato o desobediencia (sola o combinada), mientras que el carácter sacrílego apenas figura mencionado y únicamente en combinación con los otros $(4,6 \%)$. Si nos centramos en los casos posteriores al Concilio, la violencia se reduce ligeramente $(73,6 \%)$ y también las injurias dentro de aquella (32\%), quedando relegada la violencia física, salvo excepciones, a colectivos inferiores (sobre todo capellanes); pero lo más llamativo es el enorme peso que adquieren las causas con desacato/desobediencia $(55,6 \%)$, que relacionamos con la más férrea regulación sobre este aspecto de las constituciones capitulares postridentinas.

Los capitulares compostelanos compartieron las concepciones de sus coetáneos sobre el honor y el uso de la violencia ${ }^{88}$. Solo hay que examinar la descripción de los delitos verbales para comprobarlo: insultos personales (loco, majadero, idiota, necio, babieca, mentiroso, infame, "baladronazo", ruin, borracho, "asno albardado", bestia, piojoso, bigardo, desvergonzado, afrontado, roñoso, sarnoso), amenazas ${ }^{89}$, alusiones o ataques al linaje y/o limpieza de sangre (hijo de padre desconocido, puerco, marrano, "hideputa", "puto escribanejo", "judío caparroso", "judiolo", "aunque sois hijo de quien sois", "el padre del dicho (...) abía tenido mejores alacayos que no él", "borrón porquino de no nada", de mala crianza), a la condición social ("hijo de un carretador de vino" o de un remero, mesonero, bellaco, "villano mantero", "civil sucio", "comuneros"), a la categoría beneficial (ser mejor o igual que el otro, "no ser papa para mandar callar"), a la condición económica (ser mejor a pesar de tener menos dinero que el otro), al respeto que da la edad ("rapaz merdoso", rapazuelo, mozo), etc.

88 A este respecto, véase Rico Callado, op. cit. (nota 31), pp. 9-36. La importancia que Trento da a la honestidad y moderación verbal se puede apreciar, por ejemplo, en las constituciones sinodales de 1576: "Y por quanto, no solamente en el hábito exterior se muestra la honestidad y religión de las vidas, si no también y principalmente en la conuersación y pláticas sanctas y buenas. Por ende, amonestamos y encargamos a todos los clérigos de orden sacro, y en especial a los rectores, que tengan y muestren en sus palabras y conuersación honestidad y humilde grauedad, no fingida, si no que nazca del menosprecio del mundo y de coraçón todo ocupado en Dios. Y no sean dissolutos en palabras o reyr, si no mansos y humildes en hablar y responder, aunque sean prouocados e injuriados. Sean sus pláticas no de cosas profanas y vanas, sino de edificación y exortación a virtud, de manera que s vida y costumbres sean a los legos exemplo y les vengan a tener respecyo y reurencia, por donde les puedan aprouechar, aconsejándoles lo bueno y reprehendiéndoles con charidad y humildad lo malo, en especial, el abuso de juramentos y blasphemias y murmuraciones de próximos, o otros defectos communes" (Constituciones synodales del arçobispado de Sanctiago, hechas por el Illustríssimo y Reuerendíssimo señor Don Francisco Blanco, arçobispo de la Sancta Yglesia de Sanctiago..., Santiago, Luis de Paz, 1601, fol. 64-64v).

89 Por ejemplo, el doblero Pedro Fernández le dijo airado al clérigo Jácome Álvarez "que juraba a Dios y a una cruz que hizo en la frente con la mano derecha que antes que saliese de la yglesia que él le daría con él o en la cabeza" (información y auto de jurisdicción, 16-17 de mayo de 1566, ACS, P 37, Protocolos Notariales, fol. $127-127 v)$. 
Otro tanto ocurre con los delitos físicos, tanto ademanes (levantar el puño, amenazar con unas llaves, poner la mano bajo la sobrepelliz o sobre un arma ${ }^{90}$ ), injurias (meter los dedos en la nariz del otro, tirarle dos higos a los ojos) o agresiones, algunas con sangre (empujones, bofetones, coger de las barbas y los carrillos, tomar por las orejas, coger del hábito, "dar de palos", cortar un dedo, lanzar una pedrada, azotar, dar un puntapié a la barriga).

Pero también era considerable el escándalo, es decir, la publicidad negativa de tales actos, sobre todo en determinado espacio y tiempo. Respecto a los lugares de delito que se mencionan (108 casos), solo dos (1,8\%) no son en la catedral o junto a ella ${ }^{91}$. La mayor parte se producen en los dos ámbitos comunes más habituales y controlados normativamente: el coro $(45,4 \%)$ y la sala capitular $(27,8 \%)$. Una pequeña parte $(9,3 \%)$ acaecen en espacios más sagrados - de ahí que se cometan sacrilegios ${ }^{92}$ como el altar mayor y el espacio entre coros delante de aquel -donde se guardaban el Santísimo Sacramento y las reliquias del apóstol Santiago-, la capilla mayor y el Tesoro - donde se guardaban la mayor parte de las reliquias-. El resto de los casos suceden en la Praza da Quintana, el claustro, el trascoro, el trasaltar de la Preñada, diversas capillas (del Rey de Francia, de don Lope, de San Pedro, la Corticela), en la sacristía de abajo o en las naves (transepto, de la epístola, de la Preñada). En cuanto a los tiempos que se reseñan por el especial decoro que exigen figuran las horas canónicas y oficios divinos, pero, sobre todo, procesiones y festividades (el martirio y la sagración de Santiago Apóstol, Navidad, Epifanía, Corpus Christi, Nuestra Señora de Septiembre, Natividad de Nuestra Señora, Víspera de la Purificación y Presentación de Nuestra Señora, san Andrés...).

\section{Condenados y agredidos}

Si clasificamos quiénes son condenados y/o corregidos como agresores (tabla ${ }^{0}$ 3 ) hay que considerar diversos factores que explican los distintos valores porcentuales de unos cuerpos u otros. Cuando se hace referencia al estatuto en las fuentes, la mayor parte de las veces se alude a la corrección y castigo de beneficiados y ministros de la catedral: eso explica que la absoluta mayoría de sentenciados $(86,2 \%)$ en los autos de jurisdicción pertenezcan al estamento clerical; además, la estructura interna del clero capitular compostelano ${ }^{93}$ justifica que el cuerpo

90 A pesar de los mandatos reiterados del cabildo (véase Iglesias Ortega, op. cit. (nota 6), pp. 152, 190 y 329-330), hasta 1558 se registran cuatro casos de dignidades o canónigos portando armas; a partir de ahí, los cuatro restantes (1572-1601) afectan a músicos (cantor, ministriles y organista). Esto demuestra la efectividad tridentina en este aspecto, que es tratado tanto en las constituciones sinodales (op. cit. (nota 88), fols. 62v-63) como capitulares (Iglesias Ortega, op. cit. (nota 6), p. 190).

91 Uno de ellos es cierta cuestión y escándalo entre algunos beneficiados y el alguacil Rengifo (17 de septiembre de 1524) en la Rúa Nova y Fonte do Sequelo (ACS, IG 481, Actas, Libro n ${ }^{\circ} 7$, fol. 75v), y el otro cierto altercado, descortesía y desacato del canónigo Baltasar de Sandoval con el canónigo Alonso Calviño (1 de septiembre de 1601), yendo a visitar la obra de la casa en que vivía (ACS, IG 558, Actas, Libro nº 21, fol. 119).

92 También lo fue, por ejemplo, la rotura de las hojas de un breviario.

93 En 1578, tras un proceso paulatino de supresión de canonjías y raciones a lo largo del siglo XVI, el contingente del alto clero catedralicio compostelano se fija en 20 dignidades, 35 canónigos y 9 racioneros (véase Iglesias Ortega, op. cit. (nota 6), pp. 47-55 y 515-531). No obstante, téngase en cuenta que en la tabla computamos también como racioneros a los nueve racioneros cantores o músicos que podía haber en el último cuarto de la centuria, tras un proceso de supresión de prebendas a su favor, que terminó con su asimilación a los racioneros "atitulados" (ibidem, pp. 117-120). 
de canónigos sea muy superior al de dignidades y racioneros; por otra parte, los espacios más conflictivos se corresponden al coro -donde, aunque el clero mayor dispone de la mayor parte de asientos, también comparten espacio con algunos clérigos menores- y a la sala capitular -donde solo podían asistir dignidades y canónigos-.

En cuanto al clero menor, el número de casos debe relativizarse, puesto que su potencial número de componentes, también sometido a un proceso de incremento general a lo largo de la centuria, era muy elevado ${ }^{94}$. Por otro lado, la mayor parte de las faltas que cometían se resolvían mediante la aplicación de los descuentos y otras penas impuestas en las constituciones capitulares, por lo que no aparecen aquí registradas; finalmente, su carácter de personal mayoritariamente no indefinido, amovible a voluntad del cabildo o de los patronos de las capillas de fundación, introduce un elemento virtualmente disuasorio de delitos. Otro tanto se podría decir de los músi$\cos ^{95}$ y resto del personal auxiliar de la catedral ${ }^{96}$.

Tabla $\mathrm{n}^{\mathrm{o}} 3$. Condenados/corregidos según su beneficio u oficio

\begin{tabular}{|c|c|c|}
\hline Beneficio / oficio & $\mathrm{N}^{\mathrm{o}}$ & $\%$ \\
\hline Dignidades & 43 & 16,3 \\
\hline Canónigos & 119 & 45,4 \\
\hline Racioneros & 30 & 11,5 \\
\hline Clero menor & 34 & 13 \\
\hline Músicos & 33 & 12,6 \\
\hline Personal auxiliar & 3 & 1,2 \\
\hline Total & 262 & 100 \\
\hline Cofrades de Nuestra Señora Concepción & \multicolumn{2}{|c|}{ Sin especificar } \\
\hline
\end{tabular}

Más interesante, si cabe, es la evolución del número de agredidos en función del tipo de agresor y los porcentajes que dentro de cada uno de estos tipos representan los de agredidos. Dejando fuera un par de casos en que se juzgan agresiones a personal externo, hemos considerado la situación pretridentina (tabla $n^{0} 4$ ) y la postridentina (tabla $n^{\circ} 5$ ). Un primer aspecto a reseñar es que la desobediencia o desacato al cabildo como institución por parte del personal catedralicio prácti-

94 A fines de siglo había de dos a cuatro dobleros, más de ochenta capellanes de fundación, veinte capellanes del coro, unos siete capellanes rectores de la ciudad, un número indeterminado de clérigos del coro y unos doce mozos de coro (ibidem, pp. 120-142).

95 El número de cantores - sin computar los racioneros músicos-se fue incrementando hasta los doce en 1581 y dieciséis en 1604; el de ministriles se quedó en cinco o seis; organista solía ser solo uno (ibidem, pp. 150-157).

96 La nómina es amplísima: dos porteros, cuatro pincernas, dos guardas del altar mayor, el portero de la librería, de uno a cuatro médicos capitulares, un cirujano, dos notarios del número y cabildo, tres sacristanes, varios lenguajeros, un campanero mayor, dos cereros (en sustitución de varias candeleras), dos lavanderas, un barrendero o barrendera, un perrero, dos relojeros, un luminario y varias luminarias, y el resto de oficiales de la obra y fábrica, esencialmente los vinculados al trabajo artístico y artesanal (ibidem, pp. 142-150 y 158-181). 
camente desaparece tras el Concilio; en segundo lugar, se puede apreciar que, de manera general, la violencia se ejerce mayoritariamente entre personas del mismo grupo o grupos del mismo rango social ${ }^{97}$; en tercer lugar, se produce un notable incremento de la violencia ejercida por determinados grupos inferiores (racioneros, clero menor y músicos) -incluso contra los grupos superiores ${ }^{98}$-, lo que debe estar relacionado con el refuerzo dotacional que se realiza desde mediados de la centuria mediante la supresión de prebendas en favor de capellanes, cantores y racioneros músicos, y la progresiva asimilación de estos últimos a los racioneros "atitulados"; por otra parte, las directrices marcadas por Trento contribuyen a potenciar todavía más la importancia que venía protagonizando la música en las funciones y celebraciones religiosas y a incrementar el control sobre los comportamientos de maestros de capilla, sochantres, cantores, ministriles y demás miembros de la capilla de música $^{99}$; para terminar, cabe señalar que hay algunas personas más propensas a entrar en conflicto, como capitulares que son provisores, los vicarios del deán o los chantres, es decir, aquellas que, por su oficio, ejercen algún un elevado poder coercitivo, mientras que los canónigos de oficio, con un alto grado de profesionalización eclesial, apenas figuran en los altercados.

97 Llama la atención que antes de 1565 no se registra ninguna agresión de un racionero hacia otro, una circunstancia que quizá se deba al escaso número de casos en que se vieron involucrados estos, lo cual, por otra parte, es también muy llamativo. En Zamora, por ejemplo, fueron los racioneros de su catedral los más implicados en el segundo tercio del XVI, eso sí, en los delitos externos (Rico Callado, op. cit. (nota 31), p. 27).

98 Por lo que atañe a los racioneros, de los cinco casos registrados de agresión a canónigos, dos son de racioneros músicos al canónigo maestro de capilla (en el fondo, se trata de músicos dotados con una prebenda), uno se produce por defender a un amigo canónigo contra otro por una deuda que existía entre ambos y otro por defender los derechos de los racioneros; el único caso de agresión a una dignidad se da contra el chantre, probablemente en el marco del poder coercitivo de este en el coro.

En cuanto al clero menor, todos los casos registrados de agresiones a superiores atañen a capellanes del coro por cuestiones de descomedimiento. Quizás uno de los más sonados fue el del capellán Alonso de Bastavales Soiglesia, contra quien se ordenó realizar la pertinente información el 15 de enero de 1599 por las libertades que se había tomado con el canónigo cardenal don Juan de Salazar, maestro de ceremonias, después de la insistencia de este último y a pesar de haber salido algunos capitulares en defensa del primero -lo que, seguramente impidió su despido inmediato-. El conflicto se arrastraba desde el verano anterior, cuando, tras humillar a Salazar, negándose inicialmente a suplir de urgencia a un clérigo del coro para llevar sobre andas el cuerpo de Santa Susana en la procesión semanal contra la peste, a pesar de suplicarle el cardenal con el bonete en la mano mientras el prelado y su cabildo decían las letanías, esperando de rodillas a la puerta de la capilla mayor. Una vez dentro, Bastavales se pasó la procesión murmurando con descomposición y cólera contra el cabildo por haber sido obligado contra su voluntad y reprendido por Salazar para que callase bajo la amenaza de darle de cabezadas -replicando que él respondería del mismo modo-. Meses después se volvió a enfrentar a Salazar, gritándole y preciándose de ser capellán tanto como él cardenal por haber mandado descontarle una hora al no guardar el orden debido en el coro tres semanas antes por haber incensado mal y muy rápidamente cuando aquel oficiaba con capa en las vísperas - reiterando la misma actitud al día siguiente con el canónigo cardenal Barros- (ACS, IG 557, Actas, Libro $n^{\circ}$ 20, fol. 771; ACS, IG 284, Jurisdicción del Cabildo. Procesos varios, ejecutorias, breves y autos sobre el Beate Iacobe, "Documentos sobre el Beate Jacobe y otros referentes a la jurisdicción del Cabildo", fols. 85$88 \mathrm{v})$.

99 Un ejemplo en Iglesias Ortega, A.: “«Terneras y ternerillos»: la vida disipada y desidiosa del maestro de capilla Francisco de Velasco", Semata, 22 (2010), pp. 235-255. 
Tabla $n^{\circ} 4$. Agredidos según su beneficio u oficio y los del agresor (1464-1565)

\begin{tabular}{|c|c|c|c|c|c|c|c|c|c|}
\hline \multirow{2}{*}{ Agresor } & \multicolumn{8}{|c|}{ Agredidos (\%) } & \multirow{2}{*}{$\begin{array}{l}\mathrm{N}^{\mathrm{o}} \\
\text { total }\end{array}$} \\
\hline & Dig. & Can. & Rac. & Cle. & Mús. & Benef. & Per. & Cabildo & \\
\hline Dignid. & 23,3 & 26,7 & 3,3 & 13,3 & 3,3 & 0 & 0 & 30 & 30 \\
\hline Canóni. & 13,2 & 51,6 & 2,2 & 1,1 & 5,5 & 2,2 & 2,2 & 22 & 91 \\
\hline Racion. & 0 & 33,3 & 0 & 33,3 & 0 & 16,7 & 0 & 16,7 & 6 \\
\hline Clero m. & 0 & 0 & 16,7 & 33,3 & 16,7 & 0 & 16,7 & 16,7 & 6 \\
\hline Músicos & 0 & 62,5 & 0 & 12,5 & 0 & 12,5 & 0 & 12,5 & 8 \\
\hline P. auxil. & 0 & 100 & 0 & 0 & 0 & 0 & 0 & 0 & 2 \\
\hline Total & 13,3 & 44,7 & 2,8 & 7 & 4,9 & 2,8 & 2,1 & 22,4 & 143 \\
\hline
\end{tabular}

Tabla $n^{\circ} 5$. Agredidos según su beneficio/oficio y los del agresor (1566-1602)

\begin{tabular}{|c|c|c|c|c|c|c|c|c|c|}
\hline \multirow{2}{*}{ Agresor } & \multicolumn{7}{|c|}{ Agredidos (\%) } & \multirow{2}{*}{$\begin{array}{c}N^{\circ} \\
\text { total }\end{array}$} \\
\cline { 2 - 11 } & Dig. & Can. & Rac. & Cle. & Mús. & Benef. & Per. & Cabildo & 14 \\
\hline Dignid. & 35,8 & 50 & 0 & 0 & 7,1 & 0 & 0 & 7,1 & 14 \\
\hline Canóni. & 20,7 & 62,1 & 13,8 & 0 & 0 & 3,4 & 0 & 0 & 29 \\
\hline Racion. & 6,7 & 33,3 & 60 & 0 & 0 & 0 & 0 & 0 & 15 \\
\hline Clero m. & 3,6 & 10,7 & 7,1 & 64,3 & 0 & 14,3 & 0 & 0 & 28 \\
\hline Cofrades & 0 & 0 & 0 & 0 & 0 & 0 & 0 & 100 & 1 \\
\hline Músicos & 0 & 12,5 & 12,5 & 6,25 & 68,75 & 0 & 0 & 0 & 16 \\
\hline P. auxil. & 0 & 0 & 100 & 0 & 0 & 0 & 0 & 0 & 1 \\
\hline Total & 12,6 & 34 & 17,5 & 18,4 & 11,6 & 4,8 & 0 & 1 & 103 \\
\hline
\end{tabular}

\section{Penas y castigos}

En general, las penas impuestas eran más importantes cuanto más grave fuera el delito cometido, lo cual venía determinado por el uso o no de la violencia, el grado de la misma, el grado de desacato, la reincidencia, la calidad del agredido, la existencia o no de sacrilegio, la calidad del lugar y tiempo en que se cometía, etc. Analizando los casos de todo el período estudiado (tabla $n^{\circ} 6$ ), al margen de las correcciones públicas verbales (reprensión del deán o su vicario para no volver a cometer semejante delito, apercibimiento de incurrir en penas mayores) y gestuales (obligación de hacerse amigos), las penas mayoritarias serán las económicas (multas aplicadas a un Beate Jacobe, que se suelen repartir como interpresentes ${ }^{100}$, o aplicadas a favor de la Fábrica, de pleitos capitulares y gastos de "procuratorio", de obras pías, de pobres, de conventos; compra de cera para alumbrar altares y capillas; abono de las costas del proceso; descuento cargado sobre su hoja o salario; etc.) y las carcelarias (la inmensa

100 El 12 de febrero de 1556 se ordena que "dende aquí en adelante el Beate Jacobe que se hechare a qualquiera benefiçiado o otra persona que los señores contadores de las horas lo repartan al thenor que reparten las posessiones, con tal que ganen la messa $2^{\mathrm{a}}$ y $3^{\mathrm{a}} \mathrm{y}$ los señores que se hallasen presentes en el dicho cabildo y en el coro y enfermos estantes en la dicha çibdad et non alius" (ACS, IG 515, Actas, Libro nº 15, fol. 218). 
mayoría de prisión domiciliaria, salvo los casos más graves en que se empleaba un aposento del antetesoro, de las bóvedas o de la Torre de las Campanas, donde se les cargaba de grilletes y cadenas). Del resto de penas, quizás la más destacada fuese la suspensión temporal de voto y acceso al cabildo, y, secundariamente, la suspensión de acceso al coro o al altar mayor, de empleo de capa de coro, sobrepelliz o hábito, o del ejercicio de determinado oficio (presidencia del cabildo, procurador general del cabildo, capellanías); también la prohibición de llevar armas en el coro y la tribuna se emplea como pena, aún después de Trento. Pero, en el marco evolutivo, se aprecia después del Concilio un claro descenso de las penas de cárcel y económicas en favor de un incremento de las correcciones verbales y gestuales, sobre todo de los apercibimientos a sufrir castigos mayores o despidos, produciéndose estos ahora con más frecuencia por la mayor conflictividad de capellanes y músicos.

Tabla $n^{\circ} 6$. Evolución de las tipologías de correcciones/penas

\begin{tabular}{|c|c|c|c|c|c|c|}
\hline \multirow{2}{*}{ Corrección/pena } & \multicolumn{2}{|c|}{$1464-1565$} & \multicolumn{2}{c|}{$1566-1602$} & \multicolumn{2}{c|}{ Total } \\
\cline { 2 - 7 } & $\mathrm{N}^{\mathrm{o}}$ & $\%$ & $\mathrm{~N}^{\mathrm{o}}$ & $\%$ & $\mathrm{~N}^{\mathrm{o}}$ & $\%$ \\
\hline Multas y costas & 69 & 30,3 & 60 & 24,3 & 129 & 27,2 \\
\hline Amistad & 37 & 16,2 & 33 & 13,4 & 70 & 14,8 \\
\hline Cárcel & 52 & 22,8 & 17 & 6,9 & 69 & 14,5 \\
\hline Reprensión fraternal & 11 & 4,9 & 47 & 19 & 58 & 12,2 \\
\hline Descuento & 23 & 10,1 & 25 & 10,1 & 48 & 10,1 \\
\hline Apercibimiento & 1 & 0,4 & 38 & 15,4 & 39 & 8,2 \\
\hline Suspens. ingreso/voto cabildo & 27 & 11,9 & 7 & 2,8 & 34 & 7,2 \\
\hline Pérdida/prohibición armas & 1 & 0,4 & 8 & 3,3 & 9 & 1,9 \\
\hline Suspensión ingreso coro & 2 & 0,9 & 3 & 1,2 & 5 & 1,1 \\
\hline Despido & 1 & 0,4 & 3 & 1,2 & 4 & 0,8 \\
\hline Suspensión uso capa/hábito & 0 & 0 & 3 & 1,2 & 3 & 0,6 \\
\hline Suspensión servicio altar & 2 & 0,9 & 0 & 0 & 2 & 0,4 \\
\hline Suspensión uso oficio & 1 & 0,4 & 1 & 0,4 & 2 & 0,4 \\
\hline Destierro & 1 & 0,4 & 0 & 0 & 1 & 0,2 \\
\hline Examinar aprovecha estudio & 0 & 0 & 1 & 0,4 & 1 & 0,2 \\
\hline Privación antigüedad & 0 & 0 & 1 & 0,4 & 1 & 0,2 \\
\hline Total & 228 & 100 & 247 & 100 & 475 & 100 \\
\hline
\end{tabular}

En cuanto a la duración de los castigos (tabla nº 7), las penas de cárcel suelen durar pocos días ${ }^{101} \mathrm{y}$ los descuentos, hasta salir de la cárcel o ejecutarse las otras penas o, como mucho, uno o dos meses (solo antes de Trento figuran casos más longevos: el máximo, de un año); la suspensión de ingreso y voto en cabildo es más variable (el caso más extremo fue de 3 años), pero después de Trento su duración suele ser más corta.

101 Por auto del 29 de enero de 1555 se establece la prisión domiciliaria preventiva para los que delinquiesen en el 
Tabla $n^{\circ}$ 7. Duración de las penas

\begin{tabular}{|c|c|c|c|c|c|c|c|}
\hline \multirow{2}{*}{ Pena/castigo } & \multirow{2}{*}{ Indefin. } & \multirow{2}{*}{$\begin{array}{c}\text { Hasta } \\
\text { cumplir }\end{array}$} & \multicolumn{5}{|c|}{ Meses } \\
\cline { 4 - 9 } & & & $<1$ & $1-2$ & $3-5$ & $6-11$ & $12-36$ \\
\hline Cárcel & 21 & 7 & 36 & 5 & 0 & 0 & 0 \\
\hline Descuento & 6 & 12 & 10 & 16 & 2 & 1 & 1 \\
\hline Susp. cabildo & 6 & 0 & 2 & 6 & 5 & 2 & 13 \\
\hline Susp. coro & 2 & 0 & 0 & 2 & 1 & 0 & 0 \\
\hline $\begin{array}{c}\text { Susp. uso capa/ } \\
\text { hábito }\end{array}$ & 2 & 0 & 0 & 0 & 1 & 0 & 0 \\
\hline Susp. altar & 0 & 0 & 0 & 0 & 0 & 0 & 2 \\
\hline Susp. oficio & 1 & 0 & 0 & 0 & 1 & 0 & 0 \\
\hline Total & 38 & 19 & 48 & 29 & 10 & 3 & 16 \\
\hline
\end{tabular}

El importe de las penas económicas (Tabla ${ }^{\circ} 8$ ) también es variable y, aunque siempre pesan más las de hasta 50 reales, después de Trento se produce un incremento de las penas más altas (excepcionales fueron los 1.000 ducados en que condenaron al provisor Landeras por el caso que derivó en la concordia de 1597 que vimos páginas atrás). Sin embargo, fue bastante frecuente que el cabildo suspendiese o condonase las penas (y no solo pecuniarias) total o parcialmente cuando el reo consentía la sentencia, suplicaba el perdón y se apartaba de los recursos y apelaciones que muchas veces presentaba, sobre todo cuando desarrollaba una labor especialmente útil al servicio de la Iglesia y cabildo ${ }^{102}$. Incluso hubo que prohibir la actitud de algunos capitulares y beneficiados que, por razón de amistad, devolvían, personalmente o a través de otros, toda o parte de la pena económica a algunos condenados, imponiendo castigos muy duros por ello ${ }^{103}$.

Tabla $\mathrm{n}^{\circ}$ 8. Importe de las penas económicas en reales (número de casos)

\begin{tabular}{|c|c|c|c|c|c|c|}
\hline & Indefin. & $1-50$ & $51-100$ & $101-200$ & $201-300$ & $300 \rightarrow$ \\
\hline Multa & 4 & 49 & 19 & 29 & 16 & 12 \\
\hline
\end{tabular}

cabildo, catedral o Praza da Quintana hasta que se sacase información y se viese en cabildo (ibidem, fol. 151v). El 11 de septiembre de 1589 se reproduce un auto capitular idéntico (ACS, IG 519, Actas, Libro nº 19, fol. 458).

102 Por ejemplo, el 24 de agosto de 1549, por cuanto les constaba que Alonso de la Peña, provisor y canónigo, estaba en paz y verdadera amistad con el canónigo Juan Álvarez Lucero, y, atento los días que había pasado en cumplimiento de la sentencia que se les hizo, considerando la importancia de sus ocupaciones como provisor, le remitieron las penas impuestas de carcelería, descuento, multa y suspensión de ingreso en cabildo (ACS, IG 513, Actas, Libro ${ }^{\circ} 13$, fol. 323v).

103 Así se ordenó el 31 de mayo de 1557, imponiendo al infractor un mes de privación de ingreso y voto en cabildo, y el abono del doble de lo devuelto (ACS, IG 515, Actas, Libro n ${ }^{\circ}$ 15, fol. 391-391v), volviéndose a ordenar por auto capitular del 8 de agosto de 1600 (ACS, IG 558, Actas, Libro ${ }^{\circ} 21$, fol. 41v). 


\section{La reincidencia}

Un fenómeno reseñable, común a otras catedrales, es el de la reincidencia ${ }^{104}$. En el período estudiado, hemos podido individualizar hasta 245 condenas y/o correcciones, de las que, al menos, 138 fueron o serían de reincidentes, lo que supone un $56,3 \%$ del total, porcentaje elevadísimo. Desde el punto de vista evolutivo, se produce un claro descenso en el porcentaje de reincidencia: $64,4 \%$ antes de que finalizasen las sesiones del concilio tridentino, $47 \%$ después de Trento. En total se identifican 54 agresores reincidentes distintos, distribuidos en función de su beneficio/oficio y del número de condenas/correcciones (tabla $\left.\mathrm{n}^{\mathrm{o}} 6\right)^{105}$. La distribución por beneficio/oficio se corresponde grosso modo con la del conjunto de condenados/corregidos, pero, aunque la mayor parte de los individuos son inculpados en solo dos ocasiones, es significativo que las reincidencias en más de dos son cometidas por canónigos y dignidades ${ }^{106}$ : con tres, el canónigo cardenal Jácome Alonso de Puga "el Viejo", el juez de Luou Juan Rodríguez de Ulloa, los canónigos Juan de Mondragón, Juan Álvarez Lucero, Rodrigo de Hevia y Baltasar Ortiz de Sandoval; con cuatro, los canónigos Fernando de la Torre "el Viejo", Gómez Rodríguez, Juan García y Fernando de Valdés "el Mozo"; con cinco, los canónigos Rodrigo Gómez Montoto, Lope Sánchez de Ulloa y Pedro Yáñez, maestro de capilla; con seis, el canónigo Álvaro de Castro; y finalmente, con once, el chantre Bernaldino Melgarejo.

Tabla $n^{\circ}$ 9. Agresores reincidentes según su beneficio/oficio (1464-1602)

\begin{tabular}{|c|c|c|c|c|c|c|c|}
\hline Condenas/correcciones & \multicolumn{7}{|c|}{ Agresores } \\
\hline N. $^{\text {o }}$ & Dig. & Can. & Rac. & Cle. & Mús. & Per. & Total \\
\hline 2 & 5 & 15 & 3 & 5 & 3 & 0 & 31 \\
\hline 3 & 2 & 4 & 0 & 1 & 1 & 0 & 8 \\
\hline 4 & 0 & 4 & 0 & 0 & 0 & 0 & 4 \\
\hline 5 & 0 & 3 & 0 & 0 & 0 & 0 & 3 \\
\hline 6 & 0 & 1 & 0 & 0 & 0 & 0 & 1 \\
\hline 11 & 1 & 0 & 0 & 0 & 0 & 0 & 1 \\
\hline Sin especificar & 1 & 0 & 0 & 3 & 1 & 1 & 6 \\
\hline Total & 9 & 27 & 3 & 9 & 5 & 1 & 54 \\
\hline
\end{tabular}

Independientemente de su larga trayectoria como capitular compostelano y de la función coercitiva de su dignidad (fue chantre ininterrumpidamente durante casi 37

104 Véase Irigoyen López, op. cit. (nota 70), p. 174; Rico Callado, op. cit. (nota 31), pp. 17 y 28-29; ídem, op. cit. (nota 40), pp. 419-420, 423 y 435; Viera y Clavijo, J. de: Extractos de las actas del cabildo de la catedral de Canarias (1514-1791), Gran Canaria, Real Sociedad Económica de Amigos del País de Gran Canaria, 2007, pp. $35,40,54,71,317$ y 458.

$105 \mathrm{Si}$ consideráramos a todos los individuos implicados de cualquier modo en las conductas indisciplinadas (como agresores y/o agredidos), la nómina se incrementaría hasta los 67.

106 Únicamente he localizado dos excepciones postridentinas con tres: el capellán del coro Baltasar Rodríguez y el tiple Lázaro de Cigales. 
años, entre 1530 y 1567), podemos calificar de "persona conflictiva" a don Bernaldino Melgarejo. Hijo ilegítimo de su antecesor, el chantre Juan Melgarejo, en 1536 se vio obligado, para evitar la vía judicial, a prometer una dote de 100 ducados a favor de la joven Mencía de Estrada, a quien "avía ynfamado malamente e corronpido su vyrgynidad [...], siendo donzella vyrgen y onesta y de buena fama"107. Hagamos un somero recorrido por sus delitos disciplinarios. Estos se producen por decir palabras injuriosas en cabildo contra el maestro de capilla Alonso Ordóñez $(1530 / 1536)^{108}$; por amenazar y proferir palabras deshonestas y feas en cabildo contra el canónigo Gómez Rodríguez, al que llama necio, majadero, bellaco, villano e hijo de un "carretador" de vino, a raíz de una discusión sobre la elección como repostero y pincerna de Juan González (1535) ${ }^{109}$; por palabras descomedidas de desacato y menosprecio de la corporación (1535) ${ }^{110}$; por injuriar en cabildo (llamándole mentiroso, "hideputa", puerco, bellaco, judío, "judiolo") al canónigo Pedro de Vaamonde, contador del rótulo, al que exigía un ducado por cierto "pan de la notiçia" (1537) ${ }^{111}$; por la desobediencia y deshonor que cometió al desagregarse del resto del cabildo, en razón de la apelación ante juez apostólico del canónigo Rodrigo Rodríguez contra su sentencia de Beate Jacobe (1551) ${ }^{112}$; por la diferencia que tuvo en el coro con el cardenal Juan Martínez Ternero sobre el contar de las horas (1552) ${ }^{113}$; por palabras descomedidas y empujones contra el racionero Pedro da Cal a la puerta del coro $(1554)^{114}$; por palabras e injurias que había lanzado en la iglesia y el coro contra Gómez Álvarez, capellán de San Jorge (1555) ${ }^{115}$; por causas y razones que movían al cabildo y porque convenía "al seruiçio de nuestro Señor y desta santa Yglesia e actoridad della" (1557) $)^{116}$; por haberse descomedido públicamente con ciertas palabras ("çiuil", "suzio") y descortesías (le cogió del manto del hábito, dándole un empujón) en la plaza de la Quintana de Palacios con un religioso del monasterio de san Francisco llamado fray Justo, después de que este hubiese predicado en la catedral el sermón del Viernes de Ramos, al sentise aludido cuando dijo que los que no perdonaban injurias eran villanos y de villana condición -reprobó su sermón, pues "lo avía dicho como un asno albardado y muy bellacamente e que si no fuera por un poco que lo fuera derrocar del púlpito y que le quisiera dar de inpuxones"-; también por el puñetazo en la espalda, las injurias (bestia, bellaco, borracho) y amenazas que profirió contra el capellán Alonso González cerca del altar mayor, durante la procesión del Jueves Santo, y por las amenazas que hizo al clérigo orensano Alonso Méndez el Viernes Santo (1558) ${ }^{117}$; y, finalmente, por excederse en su jurisdicción al hacerle título y colación de una cardenalía y beneficio a Rodrigo Pachistre, tras

\footnotetext{
107 Iglesias Ortega, op. cit. (nota 87), t. I, pp. 731-735.

108 ACS, IG 715, Tomos de Varia, Segunda serie, t. III, doc. 199dup., fols. 1-8v.

109 ACS, IG 284, Jurisdicción del Cabildo. Procesos varios, ejecutorias, breves y autos sobre el Beate Iacobe, "Documentos sobre el Beate Jacobe y otros referentes a la jurisdicción del Cabildo", fols. 2-6v.

110 Ibidem, fol. 7-7v.

111 AHUS, Protocolos Notariales, Santiago de Compostela, S 194, fols. 241-242v.

112 ACS, IG 284, Jurisdicción del Cabildo. Procesos varios, ejecutorias, breves y autos sobre el Beate Iacobe, "Documentos sobre el Beate Jacobe y otros referentes a la jurisdicción del Cabildo", fol. 34-34v.

113 ACS, IG 515, Actas, Libro ${ }^{\circ} 15$, fol. 2r.

114 Ibidem, fols. 118 y 123.

115 Ibidem, fols. 176-176v y $178 \mathrm{v}$.

116 Ibidem, fol. 417.

117 ACS, IG 284, Jurisdicción del Cabildo. Procesos varios, ejecutorias, breves y autos sobre el Beate Iacobe, "Documentos sobre el Beate Jacobe y otros referentes a la jurisdicción del Cabildo", fols. 35-42v.
} 
aceptar a su requerimiento ser juez apostólico ejecutor de una bula expectativa que el papa luego anuló (1558) ${ }^{118}$.

\section{Solidaridad en la violencia}

Como ya se ha demostrado en alguna que otra catedral ${ }^{119}$, ciertos delitos cometidos reflejan un componente relacional de apoyo o solidaridad entre dos o más individuos implicados.

En muchos casos, se basa en el parentesco: así, por ejemplo, el 1 de septiembre de 1514, el canónigo Gonzalo Fernández es condenado en 10 reales de plata para pleitos y negocios del cabildo por contarse por enfermo en base a un falso testimonio, mientras que a su sobrino, el racionero Álvaro López, se le condena en 4 reales de plata por haber dicho al portero del cabildo que su tío no podía acudir a la reunión capitular a la que aquel le había convocado por hallarse doliente, pero, tras ser obligado a dar testimonio jurado ante notario, confiesa que había mentido y se había ido de la ciudad ${ }^{120}$; el 2 de enero de 1554 se condena al canónigo Diego Feijoo a cuatro días de cárcel domiciliaria y se le ordena asistir a cabildo para recibir una corrección verbal y reconciliarse con el maestro de capilla Francisco de Logroño, por haber perturbado el oficio divino en coro con alboroto y palabras de rencilla durante las vísperas del Año Nuevo, debido a que este último había ordenado descontar 2 reales a su primo, el cantor Leonel Feijoo ${ }^{121}$; el 21 de febrero de 1558 condenaron al canónigo Alonso Ares do Vilar a privación de voto en cabildo y a no poder decir evangelios en el altar mayor durante un año por haber proferido palabras deshonestas e injuriosas contra el cabildo, debido a que un mes antes habían prohibido al hermano de aquel, Pedro da Fraga "el Mozo", teniente de alguacil mayor en sede vacante, seguir usando la vara de su oficio por su inexperiencia, juventud y descomedimiento con un canónigo ${ }^{122}$; ya hemos visto páginas arriba, al hablar de la conflictividad entre Arzobispo y cabildo, como el 9 de junio de 1572 fueron condenados el canónigo Lope Ochoa de Avellaneda y su tío, el deán don Baltasar López Gallo, por haber agredido al cantor Luis de Cardona en el cuarto nuevo de la catedral, durante el almuerzo que solía darse allí a todos los que iban a tomar parte de la procesión de la Consolación del día del Corpus ${ }^{123}$; en mayo de 1585, el canónigo Rodrigo de Hevia es condenado dos veces consecutivas: la primera, por haber abofeteado delante del Santísimo Sacramento a Francisco de Haro, hermano del racionero tiple Juan de Haro, y, la segunda, por negarse con desprecio a aceptar el abrazo fraternal de este último a que fue obligado en la primera sentencia, a pesar del mandato capitular ${ }^{124}$.

118 ACS, IG 515, Actas, Libro n ${ }^{\circ} 15$, fols. 447-448v.

119 Véase, por ejemplo, Rico Callado, op. cit. (nota 31), pp. 21-24.

120 ACS, IG 479, Actas, Libro n ${ }^{\circ}$, fols. 0 y 53-53v.

121 ACS, IG 284, Jurisdicción del Cabildo. Procesos varios, ejecutorias, breves y autos sobre el Beate Iacobe, "Compostellana Jurisdictionis pro (...) Capitulo (...) Ecclesie Compostellane contra (...) Archiepiscopum dicte Ecclesie eiusque promotorem fiscalem ecclesiasticum (...). Discursus. Facti et Juris pro Congregatione Aduocatorum habita die 12 aprilis" (1676); ACS, IG 515, Actas Capitulares. Libro n 15, fols. 78v-81; AHUS, Protocolos Notariales, Santiago de Compostela, S 289, fols. 240-245

122 ACS, IG 515, Actas, Libro n ${ }^{\circ} 15$, fols. 423v-424v y 433.

123 Véase notas 56-58.

124 ACS, IG 519, Actas, Libro no 19, fols. 48v, 56-60, 71-71v y 111v-113v. 
En ocasiones, entra en juego la defensa del honor de la familia o linaje, como así sucedió con la del linaje capitular de los Ulloa, que se activó en 1541 cuando el juez de Luou Juan Rodríguez de Ulloa acusó en cabildo al canónigo Rodrigo Gómez Montoto de intentar revolver cierto asunto entre Lope Sánchez de Ulloa y el provisor, a lo que Montoto reaccionó violentamente increpándole varias veces que era un "ydeputa judío" o "judío caparroso"125; igualmente, en 1542, tratando algunos clérigos y beneficiados en el coro sobre la prisión de Juan Rodríguez de Ulloa, entró con una loba sin sobrepelliz su hijo, el canónigo Lope Sánchez de Ulloa de la Fuente do Sequelo, arremetiendo contra el cabildo, exclamando "doi al diablo estos comuneros" o que "en este Cabildo no avía honbre de sangre y que entrados en cabildo no sabían lo que hazían", y quejándose públicamente de que lo habían prendido sin tener razón a ello, que bien parecía que no entraba en cabildo hombre de casta ni de conciencia, que no sabían lo que hacían y que habían de pagar de su bolsa aquello por lo que le prendieron ${ }^{126}$. Ya vimos antes que se realizó información contra el chantre Bernaldino Melgarejo por la trifulca que mantuvo en cabildo con el canónigo Gómez Rodríguez, el cual le había acusado de haber influido "con pasión" para conseguir que el cabildo favoreciera a sus criados Peregrín y Solís, y mancilló su honor al menospreciar su origen diciendo "que hera hijo de mejor padre quel dicho chantre, por quanto su padre hera conosçido acá e quel padre del dicho chantre no hera conosçido ni savían quien hera" ${ }^{127}$.

En otras situaciones, es evidente que existe una relación de amistad. Este sería el caso de los canónigos Diego Alonso y Juan García ${ }^{128}$, que en 1550 fueron encarcelados por cierto ruido y cuestión que tuvieron con el canónigo coadjutor Álvaro de Castro $^{129}$, y que en 1555 fueron sentenciados por las palabras de enojo y desasosiego que tuvieron en el coro con el canónigo Diego Rodríguez a la hora de nona antes de comenzar las vísperas de Santo Ildefonso ${ }^{130}$.

Otro tipo de relación sería la clientelar, como la del racionero Sebastián da Leira, condenado en 1595 por el descomedimiento de palabras que tuvo en la procesión de la Natividad de Nuestra Señora delante de la Capilla del Santísimo Sacramento del rey de Francia con el canónigo coadjutor Eliseo de las Alas Noboa acerca de una carta que el primero había escrito al canónigo Lucas Alonso de Castro sobre la cobranza de una deuda que tenía con este un hermano del canónigo Alas ${ }^{131}$. El racionero Leira era administrador de las sinecuras y tenencias del canónigo Castro ${ }^{132}$.

125 ACS, IG 284, Jurisdicción del Cabildo. Procesos varios, ejecutorias, breves y autos sobre el Beate Iacobe, "Documentos sobre el Beate Jacobe y otros referentes a la jurisdicción del Cabildo", fols. 12-14v; ACS, Protocolos Notariales, P 54, fols. 575-576v y 579; ACS, IG 512, Actas, Libro no 12, fols. 33-34v y 105-105v.

126 ACS, IG 284, Jurisdicción del Cabildo. Procesos varios, ejecutorias, breves y autos sobre el Beate Iacobe, "Documentos sobre el Beate Jacobe y otros referentes a la jurisdicción del Cabildo", fols. 15-17v; ACS, Protocolos Notariales, P 54, fols. 577-578v y P 9, fols. 67-67v; ACS, IG 512, Actas, Libro n ${ }^{\circ} 12$, fols. 87-88v, 89v y 90v.

127 Véase nota 109.

128 Puede rastrearse su relación mutua o con alguno de sus parientes en varias escrituras notariales: ACS, Protocolos Notariales, P 11, fol. 132 y P 23, fols. 79-80v, 97-98 y 413-414v; AHUS, Protocolos Notariales, Santiago de Compostela, S 232, fol. 439.

129 ACS, IG 514, Actas, Libro ${ }^{\circ}$ 14, fols. 40v-41, 43v-44 y 49v-50.

130 ACS, IG 515, Actas, Libro n ${ }^{\circ} 15$, fols. 150-151 y 159v.

131 ACS, IG 284, Jurisdicción del Cabildo. Procesos varios, ejecutorias, breves y autos sobre el Beate Iacobe, "Documentos sobre el Beate Jacobe y otros referentes a la jurisdicción del Cabildo", fols. 72-76; ACS, IG 557, Actas, Libro n ${ }^{\circ} 20$, fol. 429v.

132 Iglesias Ortega, op. cit. (nota 87), t. I, p. 589. 


\section{Conclusiones}

Hemos comprobado cómo la crisis bajomedieval coincidió con un fortalecimiento de la autonomía del cabildo catedralicio compostelano en el marco de su potestad jurisdiccional frente a la de otras instancias de poder, fundamentalmente los arzobispos, lo que derivó en una creciente conflictividad con aquellos, no resuelta tras el Concilio de Trento, del mismo modo que tampoco la profesionalización que este quiso imponer sobre el clero secular, aunque se fue implantando lentamente, no evitó la violencia y roces entre el personal catedralicio, especialmente los miembros del cabildo. Dicha violencia es reflejo de una mentalidad común a la sociedad de la que forman parte, en la que priman conceptos como el honor y el linaje. El control social que sobre dicha violencia ejerció corporativamente se desarrolló desde época bajomedieval mediante la aplicación del estatuto de corrección y punición denominado de Beate Jacobe, que siguió funcionando durante toda la época moderna. No obstante, después de Trento se percibe, de manera general, una reducción en la gravedad de los delitos juzgados y de las penas impuestas, sobre todo en los cometidos por el alto clero catedralicio. A ello ayudó sin duda, la regulación de comportamientos y obligaciones de todo el personal catedralicio impuesta en las constituciones capitulares de Francisco Blanco, que ciertamente "no evitaba roces entre los capitulares, aunque sin duda su redacción contribuyera a regular la presencia de aquellos en sus catedrales, a sistematizar sus funciones y a dar un estilo acorde con Trento a su responsabilidad fundamental, el culto"133.

\section{Bibliografía}

Cal Pardo, E.: Catálogo de los documentos medievales, escritos en pergamino, del Archivo de la Catedral de Mondoñedo (871-1492), Lugo, Diputación Provincial, 1990.

Callado Estela, E.: "Los desórdenes del canónigo de la Catedral de Orihuela José Llop. Reforma, delitos y castigo en el siglo XVII", Studia Historia. Historia Moderna, 42:1 (2020), pp. 329-349.

Callado Estela, E.: "De obispos y cabildos valencianos. Conflictividad episcopocapitular en Segorbe durante el siglo XVII", en Callado Estela, E. (ed.): Gloria, alabanza y poder. Cabildos catedrales hispánicos en la Época Moderna, Madrid, Sílex Ediciones, 2021, pp. 117-163.

Carbajal Ibáñez, T.: "El estatuto capitular de corrección y punición”, Publicaciones de la Institución Tello Téllez de Meneses, 59 (1989), pp. 525-543.

Coello de la Rosa, A.: "Conflictividad capitular y poderes locales en el Cabildo de Manila (1690-1697)", Colonial Latin American Review, $25-3$ (2016), pp. 325-350.

Coello de la Rosa, A.: "El cabildo catedralicio y los jueces adjuntos en la Lima colonial (1601-1611)", Colonial Latin American Review, 20-3 (2011), pp. 331-361.

Constituciones establecidas, por el Illustrissimo, y Reuerendissimo Señor don Francisco Blanco, Arçobispo de Santiago, iuntamente con los Illustres Señores Dean y cabildo de la dicha sancta Iglesia, y con su consentimiento, para el buen gouierno de ella, ansi en lo que toca al seruicio del Altar y Coro, y oficios de los Prebendados, y otros ministros, como al cabildo, y conseruacion de la hazienda de la mesa capitular, Santiago, s.n., 1578.

$\overline{133}$ Rey Castelao, O.: A Galicia clásica y barroca, Vigo, Galaxia, 1998, p. 155. 
Constituciones synodales del arçobispado de Sanctiago, hechas por el Illustríssimo y Reuerendíssimo señor Don Francisco Blanco, arçobispo de la Sancta Yglesia de Sanctiago..., Santiago, Luis de Paz, 1601.

Corada Alonso, A.: "Las visitas pastorales como medio para la reformación del clero capitular. Un ejemplo de la archidiócesis de Burgos”, en Martín García, A. y Pérez Álvarez, $\mathrm{M}^{\mathrm{a}} \mathrm{J}$. (coords.): Religiosidad y Reforma católica en el Noroeste de la península ibérica. Siglos XV-XIX, Madrid, Sílez Ediciones, 2019, pp. 193-217.

Cotano Olivera, F.: "Los estatutos capitulares de la Iglesia de Coria (1586)", Cauriensia, 4 (2009), pp. 461-532.

Díaz Ibáñez, J.: La Iglesia de Cuenca en la Edad Media (siglos XII-XV). Estructura institucional y relaciones de poder, Madrid, Universidad Complutense de Madrid, 1996.

Díaz Ibáñez, J.: "La potestad jurisdiccional del obispo y cabildo catedralicio burgalés durante el siglo XV”, Medievalismo, 22 (2012), pp. 75-97.

Fernández Terricabras, I.: Felipe II y el clero secular. La aplicación del concilio de Trento, Madrid, Sociedad Estatal para la Conmemoración de los Centenarios de Felipe II y Carlos V, 2000.

Fernández Terricabaras, I.: “Conflictos entre Carlos V y los cabildos catedralicios de la Corona de Castilla (1552-1556)", en Martínez Millán, J. (coord.): Carlos Vy la quiebra del humanismo politico en Europa (1530-1558), Madrid, Sociedad Estatal para la Conmemoración de los Centenarios de Felipe II y Carlos V, 2001, vol. 2, pp. 361-386.

García Oro, J.: Os Fonseca na Galicia do Renacemento. Da guerra ó mecenado. Estudio e colección documental, Noia, Toxosoutos, 2000.

Gonzalo Gozalo, Á.: El cabildo de la catedral de Burgos en el siglo XIX (1808-1902), Burgos, Cabildo Metropolitano de Burgos, Caja de Ahorros del Círculo Católico y Diputación Provincial de Burgos, 1993.

Guijarro González, S.: "Justicia eclesiástica y control social en Burgos durante el siglo XV: el castigo de las faltas y los delitos de clero en la Castilla bajomedieval", Anuario de Estudios Medievales, 46/2 (jul.-dic. 2016), pp. 787-818.

Guijarro González, S.: “The Monastic Ideal of Discipline and the Making of Clerical Rules in Late Medieval Castile", Journal of Medieval Monastic Studies, 2 (2013), pp. 131150.

Guijarro González, S.: "Disciplina clerical y control social en la Castilla medieval: el estatuto de corrección y punición del cabildo catedralicio de Burgos (1452)", en Arízaga Bolumburu, B. y otros (eds.): Mundos medievales: espacios, sociedades y poder, Santander, Universidad de Cantabria, 2002, vol. 2, pp. 1453-1466.

Iglesias Ortega, A.: La catedral de Santiago de Compostela y sus capitulares: funcionamiento y sociología de un cabildo en el siglo XVI, A Coruña, Diputación Provincial de A Coruña, 2012.

Iglesias Ortega, A.: Catálogo biográfico de la catedral de Santiago de Compostela. Dignidades, canónigos y racioneros del siglo XVI, Santiago de Compostela, Consorcio de Santiago y Universidade de Santiago de Compostela, 2019, 2 vols.

Iglesias Ortega, A.: "«Terneras y ternerillos»: la vida disipada y desidiosa del maestro de capilla Francisco de Velasco", Semata, 22 (2010), pp. 235-255.

Iglesias Ortega, A.: "El curriculum vitae de los capitulares en el siglo XVI: el ejemplo del cabildo catedral de Santiago", Historia y Genealogía, 2 (2012), pp. 145-174.

Iglesias Ortega, A.: "Nepotismo y patronazgo eclesiástico en la Galicia moderna: el cabildo catedralicio de Santiago de Compostela", Hispania Sacra, LXVIII, 137 (ene.-jun. 2016), pp. 259-280. 
Irigoyen López, A.: "La difícil aplicación de Trento: las faltas de los capitulares de Murcia (1592-1622), Hispania Sacra, 62 (2010), pp. 157-179.

Irigoyen López, A.: "Los conflictos entre obispo y cabildo catedralicio de Murcia tras el Concilio de Trento (1583-1606)", en Callado Estela, E. (ed.): Gloria, alabanza y poder. Cabildos catedrales hispánicos en la Época Moderna, Madrid, Sílex Ediciones, 2021, pp. $165-228$.

Lop Otín, $\mathrm{M}^{\mathrm{a}} \mathrm{J}$.: El cabildo catedralicio de Toledo en el siglo XV: aspectos institucionales y sociológicos, Madrid, Fundación Ramón Areces, 2003.

López Ferreiro, A.: Historia de la S. A. M. I. Catedral de Santiago de Compostela, Santiago de Compostela, Imp. y Enc. del Seminario Conciliar Central, 11 vols, 1898-1911.

López Gómez, Ó.: “Clérigos, canónigos y gobernantes. Disposiciones frente al conflicto en las actas de la catedral de Toledo (1466-1510)”, en Díaz Ibáñez, J. y Nieto Soria, J. M. (coords.): Iglesia, nobleza y poderes urbanos en los Reinos cristianos de la Península Ibérica durante la Edad Media, Murcia, Sociedad de Estudios Medievales, 2019, pp. 229-258.

Pérez López, S. L.: La Iglesia en la Galicia bajomedieval (1215-1563), Santiago de Compostela, Instituto Teológico Compostelano, 2003.

Pérez Rodríguez, F. J.: El Dominio del Cabildo Catedral de Santiago de Compostela en la Edad Media (Siglos XII-XIV), Santiago de Compostela, Tórculo Edicións, 1994.

Pérez Rodríguez, F. J.: La Iglesia de Santiago de Compostela en la Edad Media: el Cabildo Catedralicio (1100-1400), Santiago de Compostela, Xunta de Galicia, 1996.

Polanco Pérez, A.: "Violencia verbal en el estamento eclesiástico palentino a través de las acta capitulares durante el s. XV", Publicaciones de la Institución Tello Téllez de Meneses, 72 (2001), pp. 373-380.

Portilla González, A.: Cultura, poder y redes sociales en la Castilla medieval: el clero del cabildo de la catedral de Sigüenza durante la Baja Edad Media (ss. XIV-XV), Santander, Universidad de Cantabria, 2019.

Quintana Andrés, P. C.: A Dios rogando, y con el mazo dando. Fe, poder y jerarquía en la Iglesia canaria (El Cabildo Catedral de Canarias entre 1483-1820), Las Palmas de Gran Canaria, Cabildo de Gran Canaria, 2003.

Quintana Andrés, P. C.: "El cabildo catedral y el obispo Gutiérrez de Roza: poder y antagonismo en la diócesis de Canarias en el Seiscientos”, Boletín Millares Carlo, 20 (2002), pp. 191-215.

Rey Castelao, O.: El Voto de Santiago. Claves de un conflicto, Santiago de Compostela, Xunta de Galicia, 1993.

Rey Castelao, O.: A Galicia clásica y barroca, Vigo, Galaxia, 1998.

Rey Castelao, O.: "La Iglesia gallega en tiempos de Felipe II: la aplicación del Concilio de Trento", en Martínez Millán, J. (dir.): Felipe II (1527-1598): Europa y la monarquía católica, Madrid, Parteluz, 1998, pp. 341-364.

Rey Castelao, O: “¿Biografía o hagiografía? Memorias breves del arzobispo don Francico Blanco de Salcedo", en Rey Castelao, O. (coord.): Cuatro textos. Cuatro contextos. Ensayos de historia cultural de Galicia, Santiago, 2004, pp. 13-63.

Rico Callado, F. L.: "Las atribuciones judiciales de los cabildos catedralicios en época moderna. Conflictos y faltas de los capitulares en Salamanca: siglos XVI-XVII", Hispania Sacra, LXXI, 143 (ene-jun. 2019), pp. 233-247.

Rico Callado, F. L.: "Ruidos y rencillas en la catedral. Las faltas de los beneficiados y la jurisdicción disciplinaria del cabildo catedralicio de Badajoz en época pretridentina”, Cauriensia, 10 (2015), pp. 409-435. 
Rico Callado, F. L.: "Violencia y justicia en Zamora: un estudio sobre los comportamientos del personal del cabildo catedralicio en época pretridentina (1532-1565)", Cuadernos de Historia Moderna, 44-1 (2009), pp. 9-36.

Sánchez Aguirreolea, D.: "El derecho de asilo en España durante la Edad Moderna", Hispania Sacra, 55 (2003), pp. 571-598.

Terráneo, S.: "Los adjuntos del cabildo en la diócesis del antiguo Tucumán (1592-1699)", Anuario Argentino de Derecho Canónico, 24 (2018), pp. 163-180.

Vázquez Bertomeu, M.: La institución notarial y el cabildo compostelano (1460-1481), Santiago de Compostela, Universidade de Santiago de Compostela, 1996, 2 vols.

Vázquez Lesmes, R.: Córdoba y su cabildo catedralicio en la Modernidad, Córdoba, Publicaciones del Monte de Piedad y Caja de Ahorros de Córdoba, 1987.

Vicente Baz, R.: Los libros de actas capitulares de la catedral de Salamanca (1289-1489), Salamanca, Cabildo Catedral de Salamanca, 2008.

Viera y Clavijo, J. de: Extractos de las actas del cabildo de la catedral de Canarias (15141791), Gran Canaria, Real Sociedad Económica de Amigos del País de Gran Canaria, 2007.

Villacorta Rodríguez, T.: El cabildo catedral de León. Estudio histórico-jurídico, siglos XII$X I X$, León, Centro de Estudios e Investigación "San Isidoro", Caja de Ahorros y Monte de Piedad de León, Archivo Histórico Diocesano, 1974. 